Marcin Feltynowski

ROZDZIAŁ IV

\title{
Dostępność systemu oświaty w województwie łódzkim w kontekście wzmacniania wartości kapitału ludzkiego $\mathrm{w}$ regionie
}

\section{Wstęp}

Proces kształtowania i rozwoju kapitału ludzkiego rozpoczyna się w miejscu zamieszkania i kontynuowany jest w przedszkolu, szkołach, uczelniach wyższych oraz w pracy zawodowej. Edukacja postrzegana jest w teorii jako element inwestycji w kapitał ludzki, gdyż rozwój nawet podstawowych umiejętności jest ważnym czynnikiem w działalności twórczej i produkcyjnej. Przyjmuje się, że edukacja pozwala na kreowanie wyższego poziomu kapitału ludzkiego, dlatego też często podkreśla się wagę pozytywnych zmian społecznych, których podstawą są dobrze wykształceni obywatele. Panuje również przekonanie, że zwiększanie jakości edukacji promuje wzrost i rozwój gospodarczy ${ }^{1}$. Zatem aby inwestować we wzrost wartości kapitału ludzkiego, należy między innymi dbać o rozwój systemów edukacji, głównie dlatego, żè :

- nowe pokolenia muszą wykorzystywać w procesie tworzenia elementy wiedzy zgromadzone już wcześniej;

- nowe pokolenia trzeba kształcić, w jaki sposób istniejąca wiedza powinna być wykorzystana w procesie twórczym i produkcji;

\footnotetext{
* Adiunkt, Katedra Gospodarki Regionalnej i Środowiska, Wydział Ekonomiczno-Socjologiczny, Uniwersytet Łódzki. E-mail: marcinf@uni.lodz.pl

${ }^{1}$ D. A. Olaniyan, T. Okemakinde, Human Capital Theory: Implications for Educational Development [w:] European Journal of Scientific Research, Dec 2008, Vol. 24 Issue 2, s. 157-162; EBSCO.

${ }^{2}$ J.B. Babalola, Budget Preparation and Expenditure Control in Education [w:] J.B. Babalola (red.), Basic Text in Educational Planning. Ibadan Awemark Industrial Printers 2003 [za:] D. A. Olaniyan, T. Okemakinde, Human Capital Theory: Implications for Educational Development [w:] European Journal of Scientific Research, Dec 2008, Vol. 24 Issue 2, s. 157-162; EBSCO.
} 
- ludzie muszą być zachęcani do rozwijania zupełnie nowych pomysłów, produktów, procesów i metody, za pomocą kreatywnego podejścia.

$\mathrm{Z}$ tej perspektywy proces akumulacji kapitału ludzkiego uzależniony jest zarówno od uczniów czy studentów, jak i od umiejętnego dostosowywania systemu edukacyjnego do wymagań rynku i jego konsekwentnej kontroli oraz podnoszenia jakości kształcenia. Połączenie tych dwóch elementów, to jest „dobrego” systemu oświaty i potrzeb edukacyjnych powinno skutkować lepszym wykorzystaniem środków na edukację. Zatem zarówno wychowywanie na poziomie przedszkolnym, jak i wykształcenie na poziomie podstawowym, gimnazjalnym i ponadgimnazjalnym kształtują społeczeństwo oraz w konsekwencji konkurencyjność regionów. Należy także podkreślić, że system oświaty to także ośrodki doskonalenia i podnoszenia kwalifikacji samych nauczycieli.

Z uwagi niematerialny charakter, mobilność czy wewnętrzną niejednorodność zasobów kapitału ludzkiego trudno jest w sposób zupełny mierzyć jego wartość ${ }^{4}$. Stąd w pracy uwagę poświęcono przede wszystkim ocenie ilościowej bazy, z której społeczność lokalna może skorzystać w celu akumulacji kapitału ludzkiego.

System oświaty obowiązujący obecnie w Polsce jest efektem reformy realizowanej od 1 września 1999 roku. Wynikiem reform oświatowych było przekształcenie funkcjonującego od lat sześćdziesiątych dwustopniowego systemu w system trzystopniowy. Obecnie dzieci i młodzież uczą się w sześcioletnich szkołach podstawowych, trzyletnich gimnazjach, a następnie podejmują kształcenie w szkołach ponadgimnazjalnych ${ }^{5}$.

${ }^{3}$ V. Vandenberghe, Economics of Education. The Need to go Beyond Human Capital Theory and Production-Function Analysis [w:] Educational Studies, Jul 99, Vol. 25 Issue 2, s. 129-143; EBSCO.

${ }^{4}$ Z. Przygodzki, Region wiedzy - wiedza i kapitat ludzki a rozwój regionu [w:] A. Nowakowska, Z. Przygodzki, M. E. Sokołowicz, Region w gospodarce opartej na wiedzy. Kapitat ludzki, innowacje, korporacje transnarodowe, Wydawnictwo Difin, Warszawa 2011, s. 46-47.

${ }^{5}$ Do grupy szkół ponadgimnazjalnych zgodnie z zapisami ustawy o systemie oświaty zaliczone zostały: (Artykuł 9 ustawy z dnia 7 września 1991 r. o systemie oświaty, Dz. U. 1991 Nr 95, poz. 425 , z późn. zmianami)

- $\quad$ zasadnicze szkoły zawodowe, w których kształcenie trwa od 2 do 3 lat i umożliwia kształcenie w liceach i technikach uzupełniających;

- licea ogólnokształcące kształcące przez 3 lata i uprawniające do uzyskania świadectwa dojrzałości;

- licea profilowane, w których kształcenie trwa 3 lata, pozwala na uzyskanie zawodu i umożliwia uzyskanie świadectwa dojrzałości;

- technika, w których kształcenie trawa 4 lata i pozwala na uzyskanie dyplomu potwierdzającego kwalifikacje zawodowe oraz uzyskanie świadectwa dojrzałości;

- dwuletnie uzupełniające licea ogólnokształcące dla absolwentów szkół zawodowych, pozwalające na uzyskanie świadectwa dojrzałości;

- trzyletnie technika uzupełniające dla absolwentów szkół zawodowych, pozwalające na uzyskanie dyplomu potwierdzającego kwalifikacje zawodowe oraz świadectwa dojrzałości; 
Większość szkół i placówek ${ }^{6} \mathrm{w}$ Polsce prowadzona jest przez samorządy terytorialne. Należy jednak pamiętać, że szkoły mogą być zakładane również przez osoby prawne i osoby fizyczne, bądź ministra oświaty. W ostatnim przypadku mogą to być szkoły i placówki szkolne, w tym o charakterze eksperymentalnym. System oświaty uzupełniają szkoły artystyczne, z tą różnicą, że nie podlegają one Ministerstwu Edukacji Narodowej, gdyż zakładane i prowadzone są przez ministra kultury i dziedzictwa narodowego. Zgodnie $\mathrm{z}$ artykułem 5 ustawy $^{7}$ prawo do zakładania i prowadzenia szkół i placówek o charakterze publicznym mają również: minister rolnictwa i rozwoju wsi - szkoły rolnicze; minister środowiska - szkoły leśne; minister sprawiedliwości - szkoły w aresztach i zakładach poprawczych, minister obrony narodowej; minister spraw wewnętrznych $\mathrm{i}$ administracji.

System szkolnictwa wspierany jest przez przedszkola, które przygotowują dzieci do obowiązku szkolnego. W roku szkolnym 2011/2012 dodatkowo obowiązkiem przedszkolnym oprócz 6-latków objęte zostały dzieci w wieku lat 5 . Wynika to z obniżenia wieku określającego obowiazzek szkolny dziecka. Obecnie wdrażane zmiany obligują dzieci do pobierania nauki od 6. roku życia do ukończenia gimnazjum, nie dłużej jednak niż do ukończenia 18 lat $^{8}$. Ważnym staje się również obowiązek nauki obejmujący dzieci w wieku 16-18 lat, które ukończyły gimnazjum. Obok przedszkoli, cały system uzupełniany jest przez: placówki oświatowo-wychowawcze, placówki kształcenia ustawicznego, placówki kształcenia praktycznego, ośrodki dokształcania i doskonalenia zawodowego, placówki artystyczne, poradnie psychologiczno-pedagogiczne, młodzieżowe ośrodki wychowawcze, placówki zapewniające opiekę i wychowanie uczniom $\mathrm{w}$ okresie pobierania nauki poza miejscem stałego zamieszkania, zakłady kształcenia i placówki doskonalenia nauczycieli, biblioteki pedagogiczne oraz kolegia pracowników służb społecznych ${ }^{9}$.

- $\quad$ szkoły policealne, w których kształcenie trwa maksymalnie 2,5 roku i kończy się uzyskaniem dyplomu potwierdzającego kwalifikacje zawodowe;

- trzyletnie szkoły specjalne przysposabiające do pracy.

${ }^{6}$ Pod pojęciem placówki rozumie się zgodnie z zapisami ustawy z dnia 7 września $1991 \mathrm{r}$. o systemie oświaty, Dz. U. $1991 \mathrm{Nr} 95$, poz. 425, z późn. zmianami, podmioty wymienione w artykule 2 pkt 3-5, 7 i 10 niniejszej ustawy, tj.: placówki oświatowo-wychowawcze, placówki kształcenia ustawicznego, placówki kształcenia praktycznego, ośrodki dokształcania i doskonalenia zawodowego, placówki artystyczne, poradnie psychologiczno-pedagogiczne, młodzieżowe ośrodki wychowawcze, placówki zapewniające opiekę i wychowanie uczniom w okresie pobierania nauki poza miejscem stałego zamieszkania oraz biblioteki pedagogiczne.

${ }^{7}$ Artykuł 5 ustawy z dnia 7 września 1991 r. o systemie oświaty, Dz. U. 1991 Nr 95, poz. 425, z późn. zmianami.

${ }^{8}$ Artykuł 15 ustawy z dnia 7 września 1991 r. o systemie oświaty, Dz. U. 1991 Nr 95, poz. 425, z późn. zmianami.

9 Artykuł 2 ustawy z dnia 7 września 1991 r. o systemie oświaty, Dz. U. 1991 Nr 95, poz. 425, z późn. zmianami. 
Nadzór nad placówkami i szkołami publicznymi i niepublicznymi sprawują kuratorzy oświaty. W przypadku szkół artystycznych funkcje te pełni minister kultury i dziedzictwa narodowego, podobnie jak w przypadku nadzoru nad szkołami rolniczymi minister rolnictwa i rozwoju wsi. Z obowiązkiem szkolnym związane jest istnienie szkół publicznych ${ }^{10}$ i niepublicznych ${ }^{11}$, podobny podział stosuje się również dla przedszkoli ${ }^{12}$.

${ }^{10}$ Zgodnie z zapisami ustawy, szkoła publiczna pozwala na uzyskanie świadectw lub dyplomów państwowych oraz dodatkowo musi: (Artykuł 7 ustawy z dnia 7 września 1991 r. o systemie oświaty, Dz. U. 1991 Nr 95, poz. 425, z późn. zmianami)

- zapewnić bezpłatne nauczanie w zakresie ramowych planów nauczania;

- $\quad$ przeprowadzać rekrutację uczniów w oparciu o zasadę powszechnej dostępności;

- $\quad$ zatrudniać nauczycieli posiadających kwalifikacje określone w odrębnych przepisach, bądź osoby niebędące nauczycielami, które mają wykształcenie odpowiednie do prowadzenia określonych zajęć;

- realizować: programy nauczania uwzględniające podstawę programową kształcenia ogólnego, ramowy plan nauczania;

- realizować ustalone przez ministra właściwego do spraw oświaty i wychowania zasady oceniania, klasyfikowania i promowania uczniów oraz przeprowadzania egzaminów i sprawdzianów.

${ }^{11} \mathrm{~W}$ systemie oświaty pojawiają się również kategorie szkół niepublicznych, posiadających, bądź nie uprawnienia szkoły publicznej. Taka klasyfikacja wynika z faktu, że szkoły niepubliczne mogą starać się o uzyskanie uprawnień równoważnych szkołom publicznym. Wymaga to od podmiotu założycielskiego, aby: (Artykuł 7 ustawy z dnia 7 września 1991 r. o systemie oświaty, Dz. U. $1991 \mathrm{Nr}$ 95, poz. 425, z późn. zmianami)

- realizował programy nauczania $\mathrm{z}$ uwzględnieniem podstaw programowych;

- realizował zajęcia edukacyjne w cyklu nie krótszym oraz w wymiarze nie niższym, niż łączny wymiar obowiązkowych zajęć edukacyjnych, określony w ramowym planie nauczania szkoły publicznej danego typu;

- stosował zasady klasyfikowania i promowania uczniów oraz przeprowadzania egzaminów i sprawdzianów zgodne z wytycznymi ministerialnymi;

- prowadził dokumentację przebiegu nauczania ustaloną dla szkół publicznych;

- w przypadku szkoły prowadzącej kształcenie zawodowe - kształcił w zawodach określonych w klasyfikacji zawodów szkolnictwa zawodowego;

- zatrudniał nauczycieli obowiązkowych zajęć edukacyjnych, posiadających kwalifikacje określone dla nauczycieli szkół publicznych.

Istnieje możliwość odstępstwa od tej zasady w przypadku, gdy minister oświaty zakwalifikuje szkołę niepubliczną, jako ośrodek eksperymentalny. (Artykuł 86 ustawy z dnia 7 września 1991 r. o systemie oświaty, Dz. U. $1991 \mathrm{Nr} 95$, poz. 425, z późn. zmianami.)

${ }^{12}$ Za przedszkole publiczne uważa się podmiot, który realizuje programy wychowania przedszkolnego, uwzględniające podstawę programową wychowania przedszkolnego, zapewnia bezpłatne nauczanie, wychowanie i opiekę w czasie ustalonym przez organ prowadzący, nie krótszym niż 5 godzin dziennie, przeprowadza rekrutację dzieci w oparciu o zasadę powszechnej dostępności oraz zatrudnia nauczycieli posiadających kwalifikacje określone w odrębnych przepisach (Artykuł 6 ustawy z dnia 7 września 1991 r. o systemie oświaty, Dz. U. 1991 Nr 95 poz. 425, z późn. zmianami). 


\section{System oświaty i jego dostępność w województwie łódzkim}

Prawidłowe funkcjonowanie systemu oświaty związane jest z dostępnością wszystkich szczebli kształcenia, począwszy od przedszkola, poprzez poziomy kształcenia obowiązkowego, kończąc na szkolnictwie ponadgimnazjalnym. Dostępność przedszkoli w powiatach województwa łódzkiego, mierzona liczbą przedszkoli na 1000 osób w wieku 3 do 6 lat $^{13}$, pozwala stwierdzić, że najwięcej tego rodzaju placówek znajduje się w Łodzi oraz w południowo - zachodniej części regionu tj. w powiecie wieluńskim i wieruszowskim. Najmniejszą dostępnością przedszkoli charakteryzują się powiaty: brzeziński, opoczyński, piotrkowski, poddębicki i rawski.

Rysunek 1. Liczba przedszkoli na 1000 osób w wieku 3-6 lat

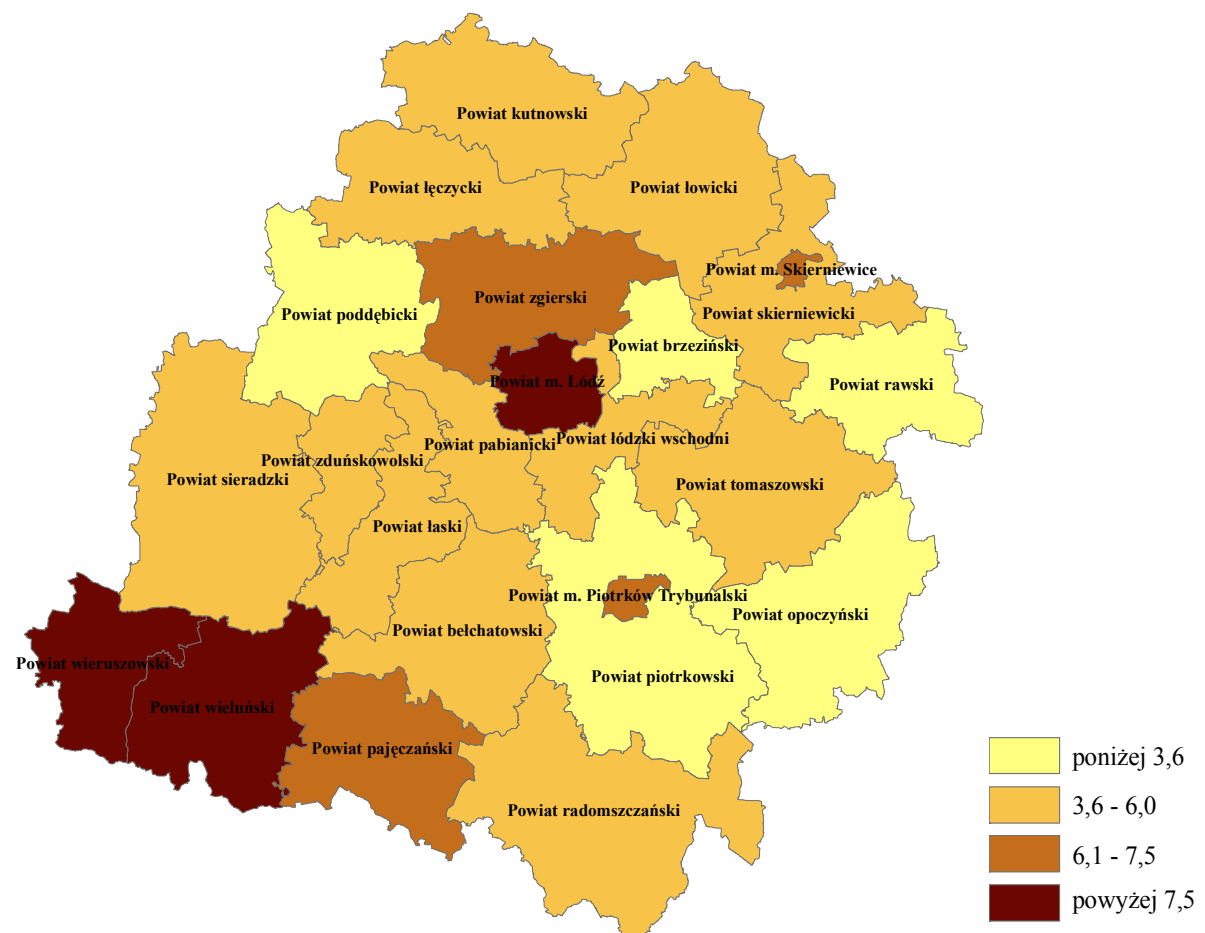

Źródło: Opracowanie własne na podstawie danych GUS i Systemu Informacji Oświatowej (SIO).

${ }^{13}$ Do obliczeń przyjęto próg wiekowy 3 do 6 lat $\mathrm{z}$ uwagi na fakt, że reforma obejmująca obowiązkiem szkolnym dzieci w wieku lat 6 , w pełni będzie realizowana od roku szkolnego 2015/2016. 
Dostępność przedszkoli w poszczególnych powiatach województwa łódzkiego zobrazować można również liczbą dzieci przypadających na jedną placówkę. Ilość ta pozwala generować lepsze warunki wychowawcze, chociażby poprzez zmniejszenie liczebności grup. Pozwala to na lepszy kontakt zarówno w relacjach dziecko - wychowawca, jak również pomiędzy wychowankami. Dostępność przedszkoli pozwala również na spełnienie warunków wskazanych ustawowo $^{14}$ odnoszących się do odległości, jaką musi pokonać dziecko pięcioletnie. Odległość ta nie może być większa niż $3 \mathrm{~km}$, w przeciwnym razie musi zostać zapewniony transport dla dzieci.

Rysunek 2. Liczba dzieci przypadająca w jednym przedszkolu

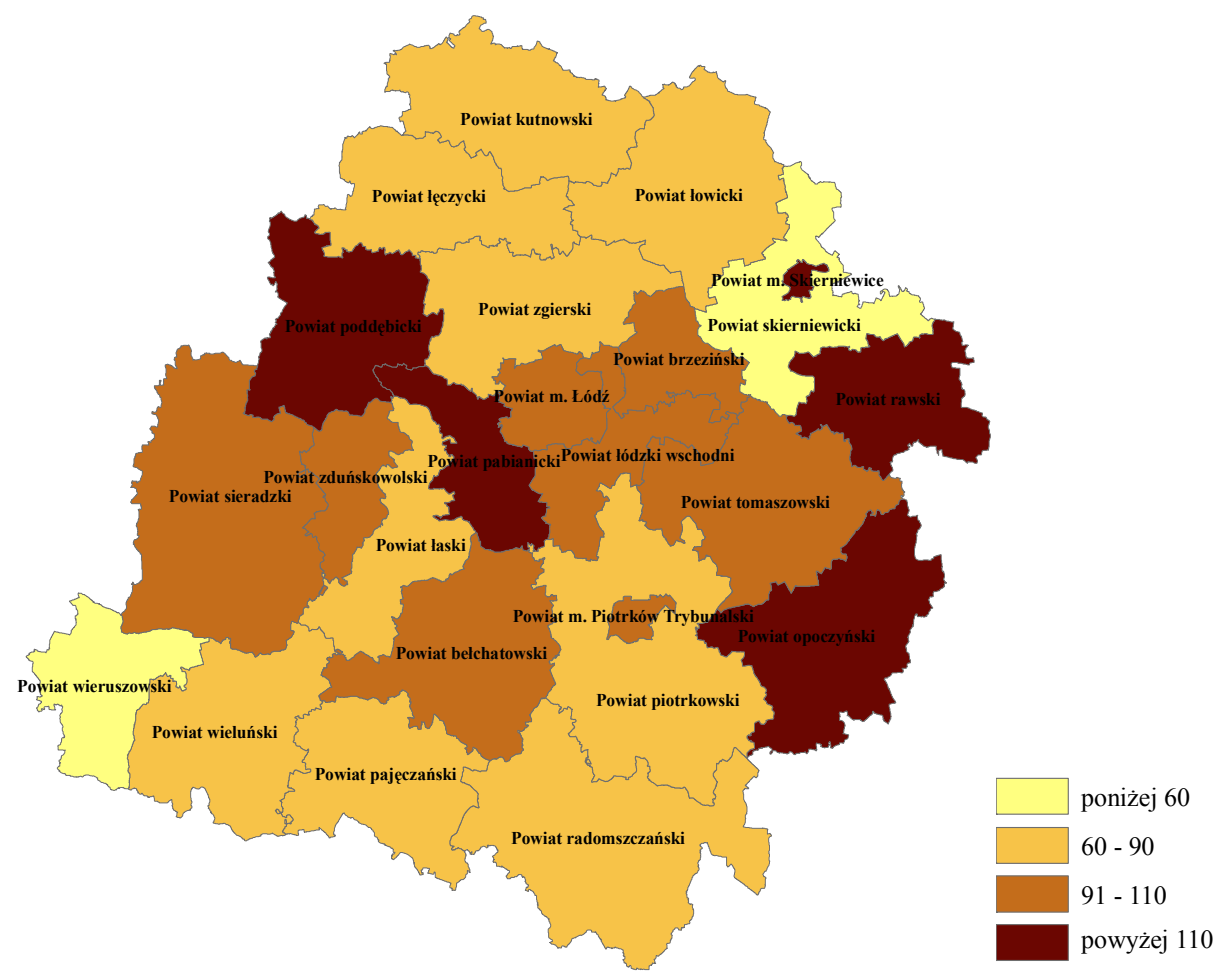

Źródło: Opracowanie własne na podstawie danych Systemu Informacji Oświatowej (SIO).

${ }^{14}$ Artykuł 14a ustawy z dnia 7 września 1991 r. o systemie oświaty, Dz. U. $1991 \mathrm{Nr} 95$, poz. 425 , z późn. zmianami. 
Najmniejsze obłożenie przedszkoli odnotowane zostało w powiecie skierniewickim oraz wieruszowskim, co pokazuje, że potencjalnie dzieci mają tam lepsze warunki wychowawcze niż w pozostałych powiatach województwa łódzkiego. Najwięcej chętnych do przedszkoli odnotowano w powiatach opoczyńskim, pabianickim, poddębickim, rawskim oraz w Skierniewicach. W przypadku powiatów opoczyńskiego, poddębickiego oraz rawskiego koresponduje to z małą dostępnością przedszkoli.

W województwie łódzkim średnie obciążenie przedszkoli wynosi 94 dzieci, co jest wartością zbliżoną do średniej krajowej, gdzie notuje się odpowiednio wielkość 93. Różnice pojawiają się natomiast w relacji przedszkola publiczne i przedszkola niepubliczne. W przypadku województwa łódzkiego, w przedszkolach publicznych opiekę znajduje średnio 102 dzieci, natomiast w ośrodkach niepublicznych zaledwie 49 dzieci. W Polsce wskaźniki te osiagają poziom odpowiednio: 101 dzieci w przedszkolach publicznych oraz 65 dzieci w przedszkolach niepublicznych.

\section{Rysunek 3. Liczba dzieci przypadająca na jeden etat w przedszkolu}

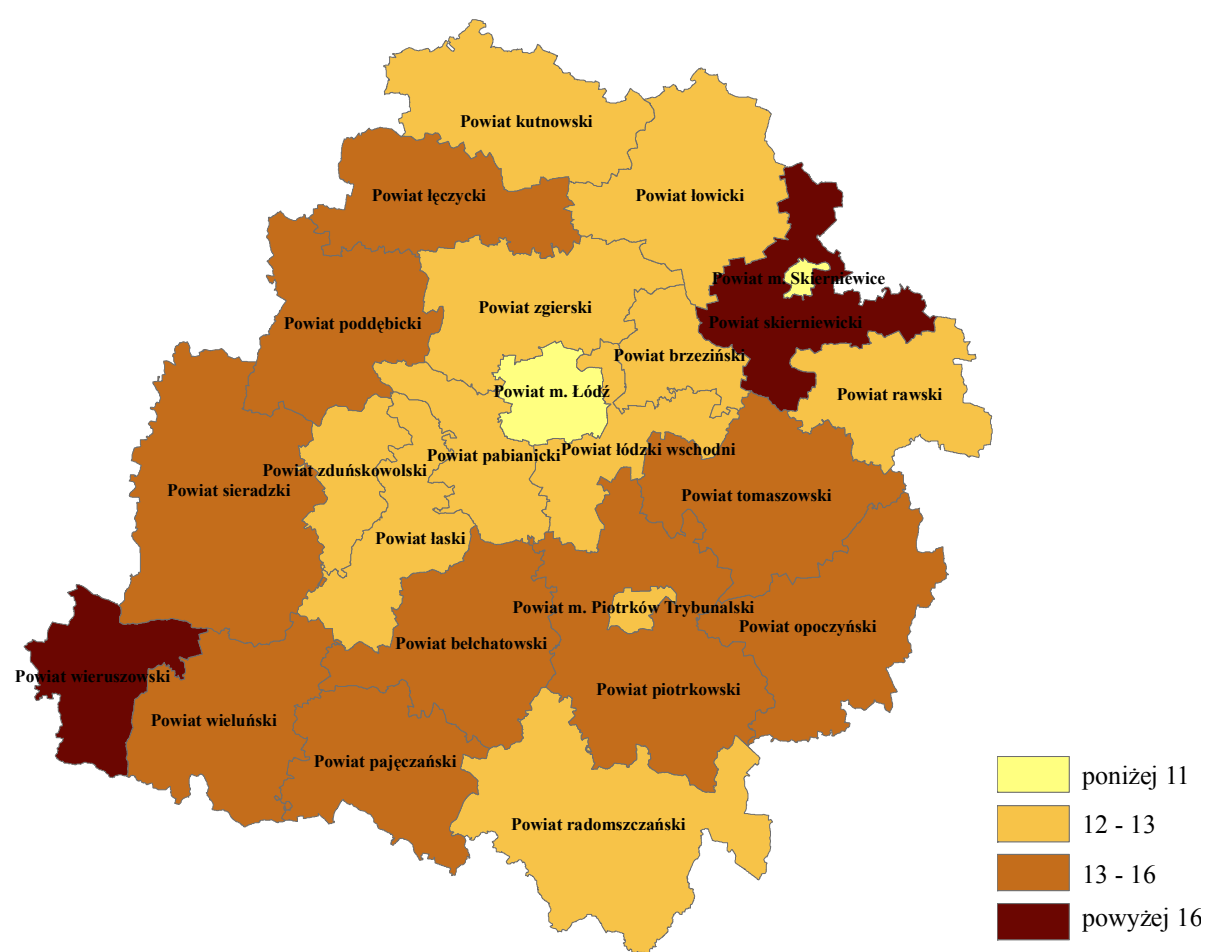

Źródło: Opracowanie własne na podstawie danych Systemu Informacji Oświatowej (SIO). 
Elementem wpływającym na kreowanie kapitału ludzkiego stają się również przepisy wskazujące maksymalną liczbę dzieci w oddziałach przedszkolnych. Zgodnie z rozporządzeniem ministra edukacji narodowej ${ }^{15}$, liczebność oddziału przedszkolnego nie może przekraczać 25 osób. Rozporządzenie wprowadza również obostrzenia $\mathrm{w}$ przypadku przedszkoli specjalnych i integracyjnych. Miarą o zbliżonym charakterze może być liczba dzieci przypadająca na zatrudnionego ${ }^{16}$.

Badania wykazały, że w Polsce w jednostkach publicznych i niepublicznych liczba dzieci przypadająca na jednego zatrudnionego wynosi 13 . W przypadku województwa łódzkiego wielkość ta została zidentyfikowana na poziomie 12 dzieci. Należy podkreślić, że najlepsze warunki wychowawcze w województwie łódzkim panują w Łodzi i Skierniewicach, gdzie liczba dzieci na jednego zatrudnionego w przedszkolu jest niższa niż 11. Najgorsze warunki występują w powiatach, w których liczba dzieci w przedszkolu jest najmniejsza tj. powiecie skierniewickim i wieruszowskim. Wskaźnik ten w przypadku tych jednostek terytorialnych wynosi odpowiednio: 18 i 21 dzieci.

Analiza dostępności i warunków nauczania w przedszkolach istotna jest z uwagi na występowanie w nich oddziałów tzw. zerówek, przygotowujących dzieci do dalszego kształcenia w szkole podstawowej. W szkołach podstawowych wyróżnia się dwa etapy kształcenia: pierwszy - obejmujący klasy I-III, nazywany również nauczaniem początkowym; drugi - obejmujący klasy IV-VI. W przypadku pierwszego etapu kształcenia dzieci mają do czynienia z jednym nauczycielem, który pełni jednocześnie rolę wychowawcy. Drugi etap edukacyjny opiera się o kształcenie z różnych przedmiotów, co wymusza uczestnictwo w tych etapach większej liczby nauczycieli. Dla zapewnienia ciągłości i skuteczności pracy wychowawczej wskazane jest, aby nauczyciel wychowawca opiekował się daną klasą przez cały etap edukacyjny ${ }^{17}$.

Dostępność szkół podstawowych na 1000 osób w wieku od 7 do 12 lat pozwala wnioskować, że najmniejsza dostępność tych jednostek zidentyfikowana została w Piotrkowie Trybunalskim i Skierniewicach. W miastach tych proponowany wskaźnik wynosi odpowiednio: 3,3 i 3 placówki na 1000 mieszkańców w wieku 7-12 lat. Najwięcej szkół podstawowych, w przeliczeniu na ludność w wieku szkolnym, zlokalizowanych jest w powiecie: pajęczańskim, skierniewickim, wieluńskim i wieruszowskim. We wszystkich jednostkach terytorial-

${ }^{15}$ Paragraf 5 załącznika nr 1 rozporządzenia Ministra Edukacji Narodowej z dnia 21 maja 2001 r. w sprawie ramowych statutów publicznego przedszkola oraz publicznych szkół, z późn. zmianami.

${ }^{16} \mathrm{Na}$ potrzeby analizy wykorzystano miarę zatrudnionych i niepełnozatrudnionych w etatach.

${ }^{17}$ Paragraf 15 załącznika nr 2 rozporządzenia Ministra Edukacji Narodowej z dnia 21 maja 2001 r. w sprawie ramowych statutów publicznego przedszkola oraz publicznych szkół, z późn. zmianami. 
nych omawiany wskaźnik osiaga poziom powyżej 10 . W przypadku pozostałych powiatów można stwierdzić, że lepsza dostępność charakteryzuje powiaty znajdujące się przy granicach województwa. Niższa wartość wskaźnika notowana jest natomiast w powiatach centralnych.

Rysunek 4. Liczba szkół podstawowych na 1000 osób w wieku 7-12 lat

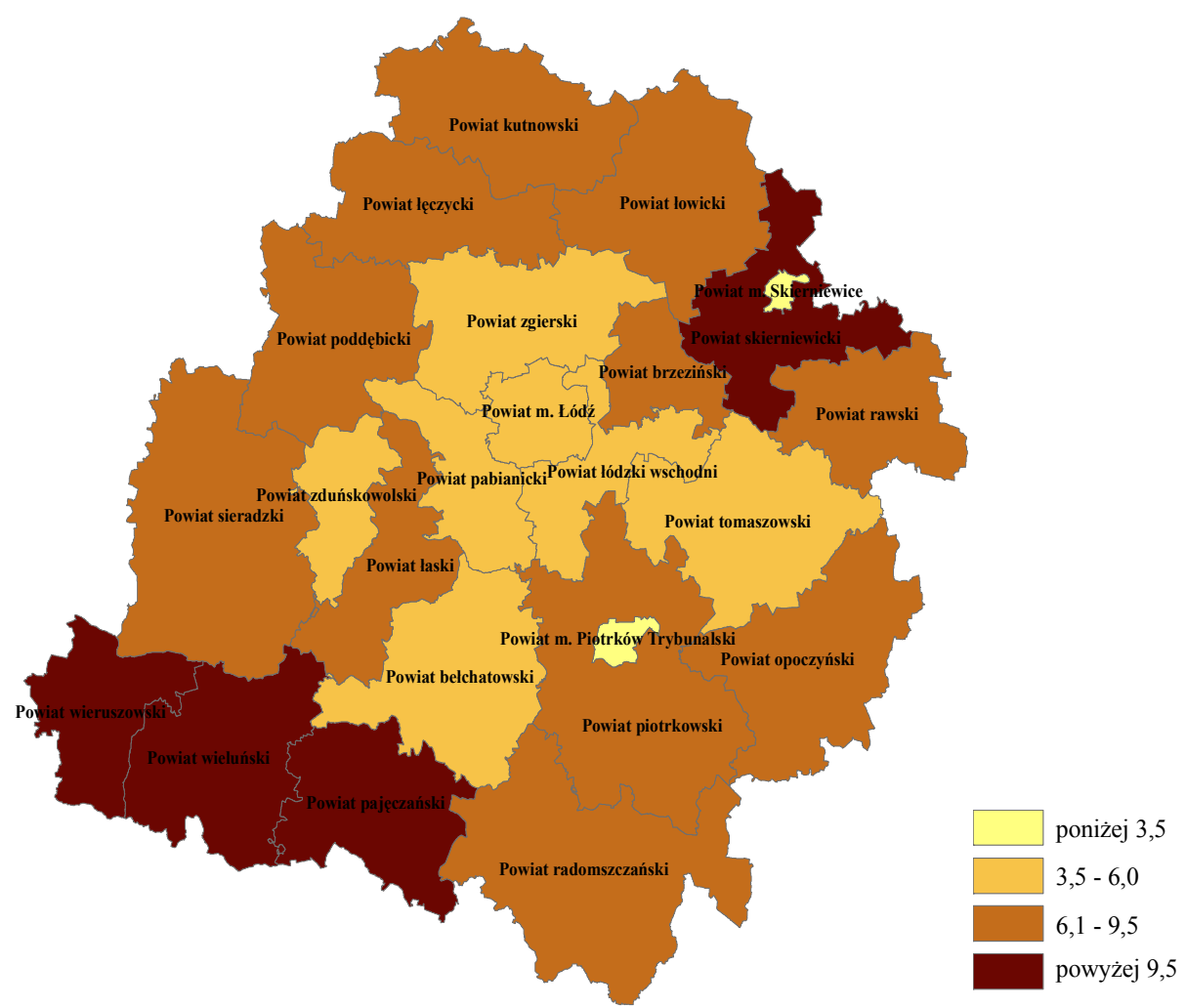

Źródło: Opracowanie własne na podstawie danych GUS i Systemu Informacji Oświatowej (SIO).

W przypadku szkół podstawowych, w ustawie o systemie oświaty występuje również zapis, dotyczący zapewnienia uczniom transportu w związku z odległością jaka dzieli ich od szkoły ${ }^{18}$. W przypadku uczniów klas I-IV odległość ta musi być mniejsza niż $3 \mathrm{~km}$, natomiast dla uczniów klas V i VI nie może przekraczać $4 \mathrm{~km}$. W przypadku gdy warunki te nie są spełnione, gmina musi zapewnić darmowy transport.

${ }^{18}$ Artykuł 17 ustawy z dnia 7 września 1991 r. o systemie oświaty, Dz. U. 1991 Nr 95, poz. 425, z późn. zmianami. 
Podjęta próba analizy średniej wielkości szkół w powiatach wskazuje, że największe placówki zlokalizowane są w miastach Piotrków Trybunalski i Skierniewice. Wielkość placówek szkolnych mierzona liczbą uczęszczających dzieci wynosi tam odpowiednio: 303 i 358 osób. Wielkość ta skorelowana jest z dostępnością szkół wyrażoną wskaźnikiem szkół na 1000 osób w wieku 7-12 lat.

Rysunek 5. Liczba dzieci przypadająca na jedną szkołę podstawową

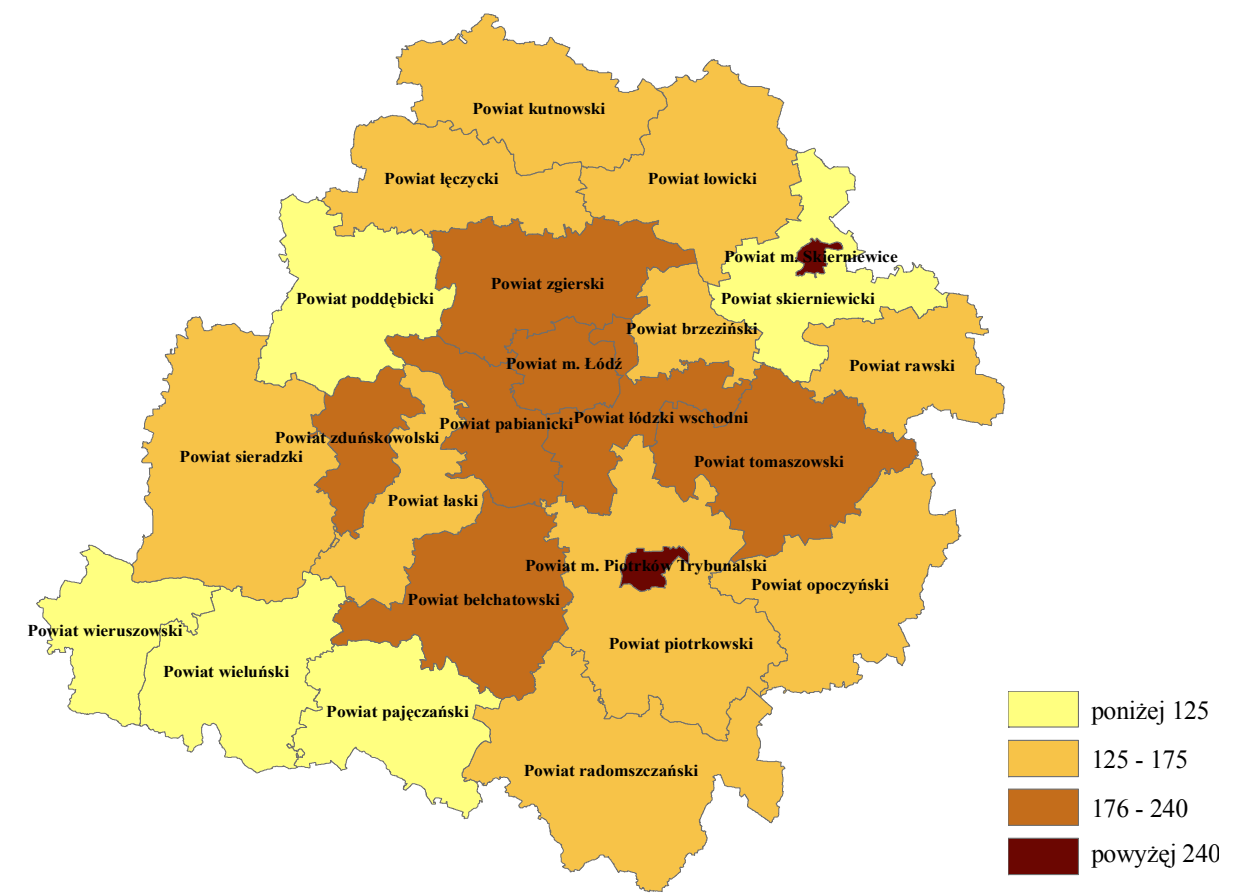

Źródło: Opracowanie własne na podstawie Systemu Informacji Oświatowej (SIO).

Podobna korelacja występuje w przypadku szkół o najniższej liczbie uczniów. Odstępstwem jest jedynie powiat poddębicki. Powiatami o najmniejszych szkołach są: pajęczański, poddębicki, skierniewicki, wieluński i wieruszowski. We wszystkich przypadkach do szkół $\mathrm{w}$ tych powiatach uczęszcza mniej niż 125 dzieci. Najniższe wskaźniki występują w przypadku powiatu skierniewickiego (średnio 85 dzieci na szkołę) oraz wieruszowskiego (średnio 94 dzieci na szkołę). Wyniki skorelowania dwóch omawianych wskaźników spowodowane są faktem, że szkoły podstawowe są jednostkami objętymi obowiązkiem szkolnym.

Porównując szkoły podstawowe publiczne i niepubliczne należy stwierdzić, że średnia wielkość tych placówek w województwie łódzkim wynosi odpowied- 
nio: 173 i 62 dzieci. Pozwala to na stwierdzenie, że szkoły podstawowe w województwie łódzkim są mniejsze pod względem obciążenia od placówek tego samego rodzaju w Polsce, gdzie wskaźniki te wynoszą: 177 i 73 dzieci.

Rysunek 6. Liczba dzieci przypadająca na jeden etat w szkole podstawowej

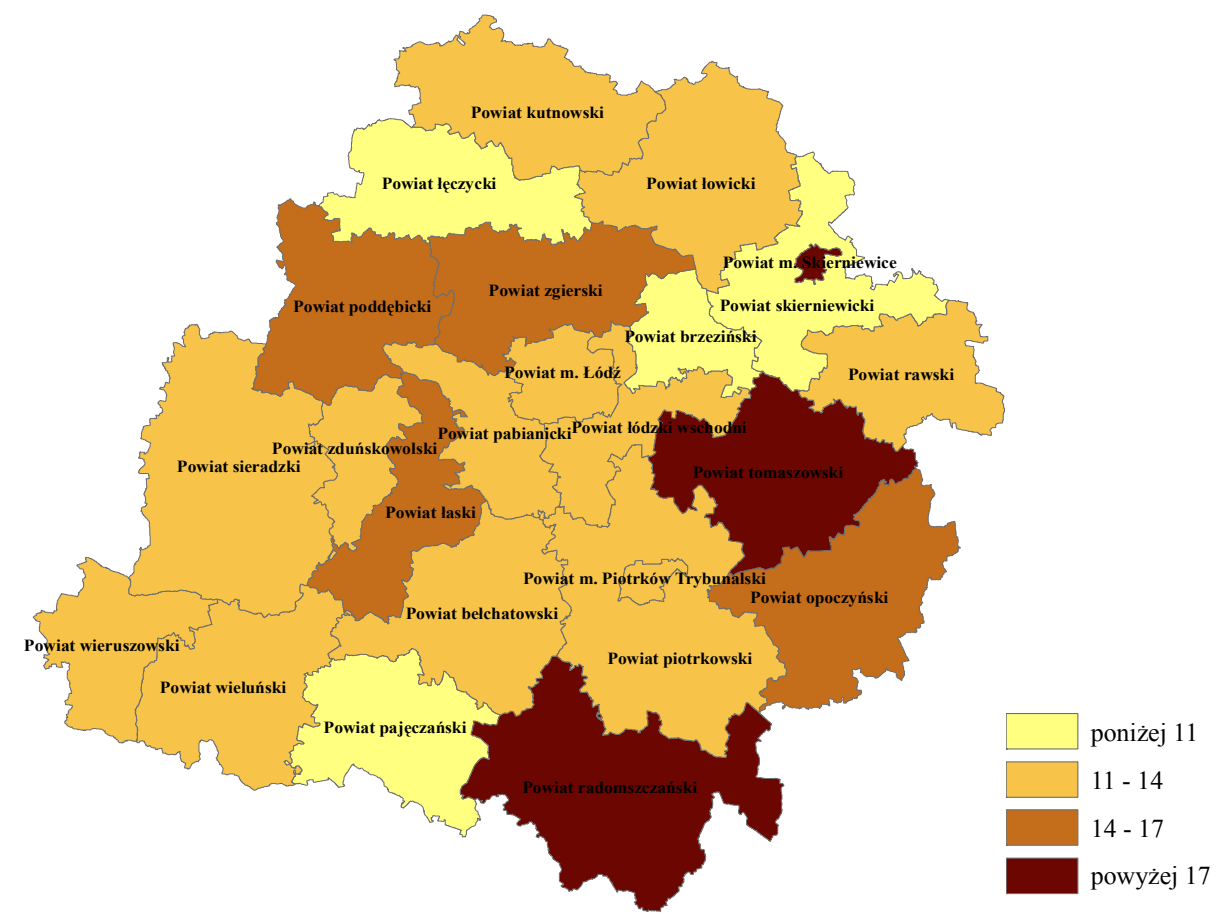

Źródło: Opracowanie własne na podstawie Systemu Informacji Oświatowej (SIO).

Analiza liczby dzieci, przypadających na etat w szkołach podstawowych pozwala wnioskować, że najlepsze warunki do rozwoju kapitału ludzkiego występują w powiatach: brzezińskim, łęczyckim, pajęczańskim i skierniewickim. Liczba dzieci na jednego nauczyciela wynosi tam mniej niż 11. Najniższy wskaźnik notuje powiat pajęczański, w którym stwierdzono 9 dzieci na nauczyciela. Największe liczby uczniów na nauczyciela odnotowują Skierniewice oraz powiaty radomszczański i tomaszowski. W przypadku miasta na prawach powiatu Skierniewice liczba ta wynosi 23 uczniów. Porównując dane uzyskane $\mathrm{w}$ poszczególnych powiatach należy uznać, że w przypadku powiatu skierniewickiego i pajęczańskiego omawiany wskaźnik powiązany jest z małym obłożeniem szkół, co w konsekwencji może przekładać się na wyższy poziom nauczania. Badanie wykazało, że liczba uczniów przypadająca na jednego nauczyciela, w odniesieniu do szkół publicznych i niepublicznych wynosi odpowiednio: 13 
i 9 dzieci. W przypadku średniej notowanej w kraju wynosi ona odpowiednio: 14 i 8 uczniów. Nasuwa to stwierdzenie, że w przypadku szkół publicznych województwo łódzkie może charakteryzować wyższy poziom nauczania, z uwagi na mniejszą liczbę dzieci.

Ostatnim obowiązkowym szczeblem edukacji w polskim systemie oświaty są szkoły gimnazjalne, w których kształcą się dzieci po ukończeniu szkoły podstawowej. Dostępność tych placówek wskazuje, że największa liczba gimnazjów w przeliczeniu na 1000 osób w wieku 13-15 lat, występuje w powiecie skierniewickim i wieluńskim. Wskaźnik ten wyniósł odpowiednio: 7,1 i 6,9 szkół na 1000 osób w wieku 13-15 lat. Najmniejszą liczbą gimnazjów charakteryzowały się powiaty znajdujące się w centrum województwa, tj.: bełchatowski, pabianicki, piotrkowski i miasto Piotrków Trybunalski. Wszystkie wskazane powiaty notują wskaźnik poniżej 4,5 jednostki na 1000 osób w określonym dla miary wieku, najniższą wartość zidentyfikowano dla Piotrkowa Trybunalskiego, gdzie jego wartość wyniosła zaledwie 3,6. Przeprowadzona analiza pozwala wnioskować, że lepszą dostępnością gimnazjów charakteryzują się powiaty zlokalizowane na północ od Łodzi.

Rysunek 7. Liczba gimnazjów na 1000 osób w wieku 13-15 lat

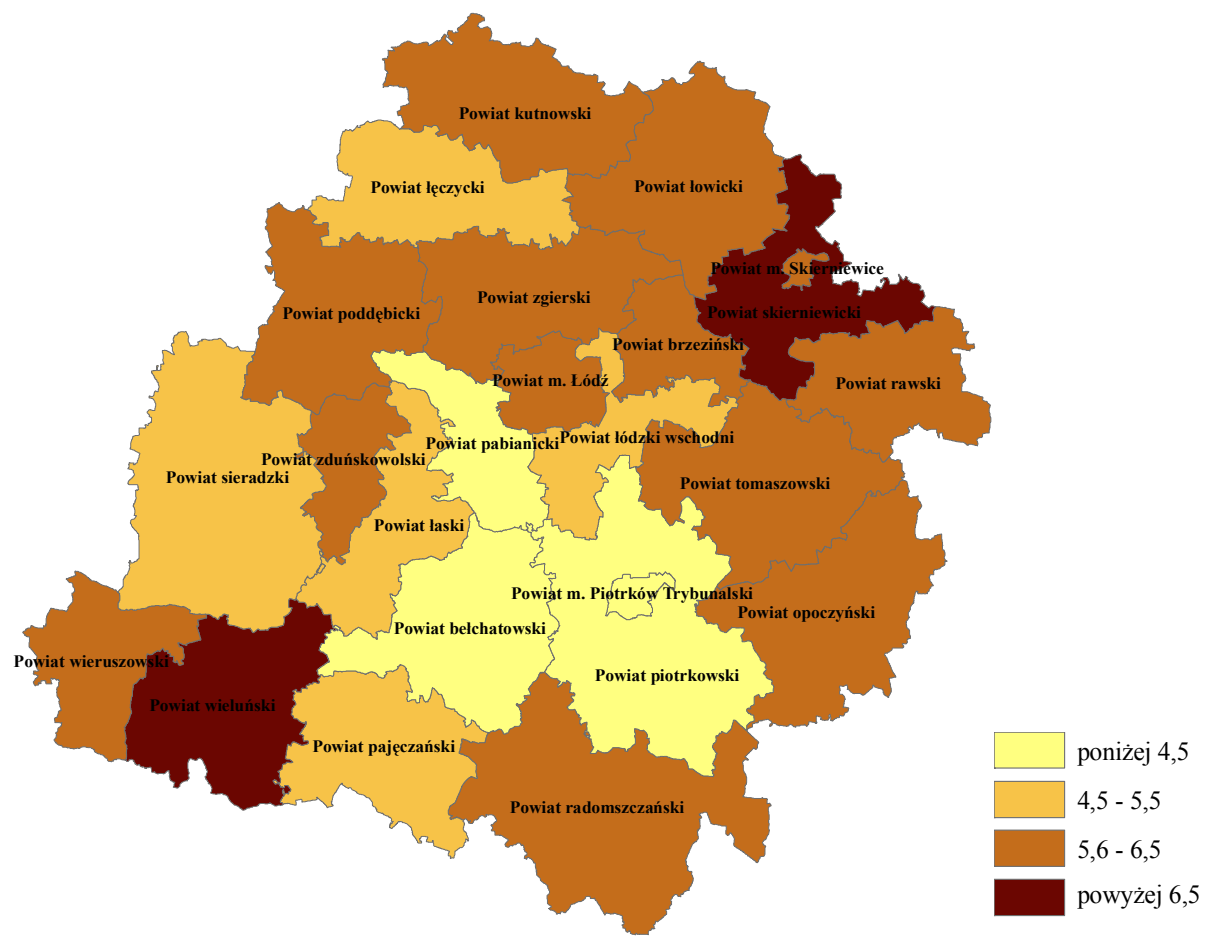

Źródło: Opracowanie własne na podstawie danych GUS i Systemu Informacji Oświatowej (SIO). 
Rysunek 8. Liczba uczniów przypadająca na jedno gimnazjum

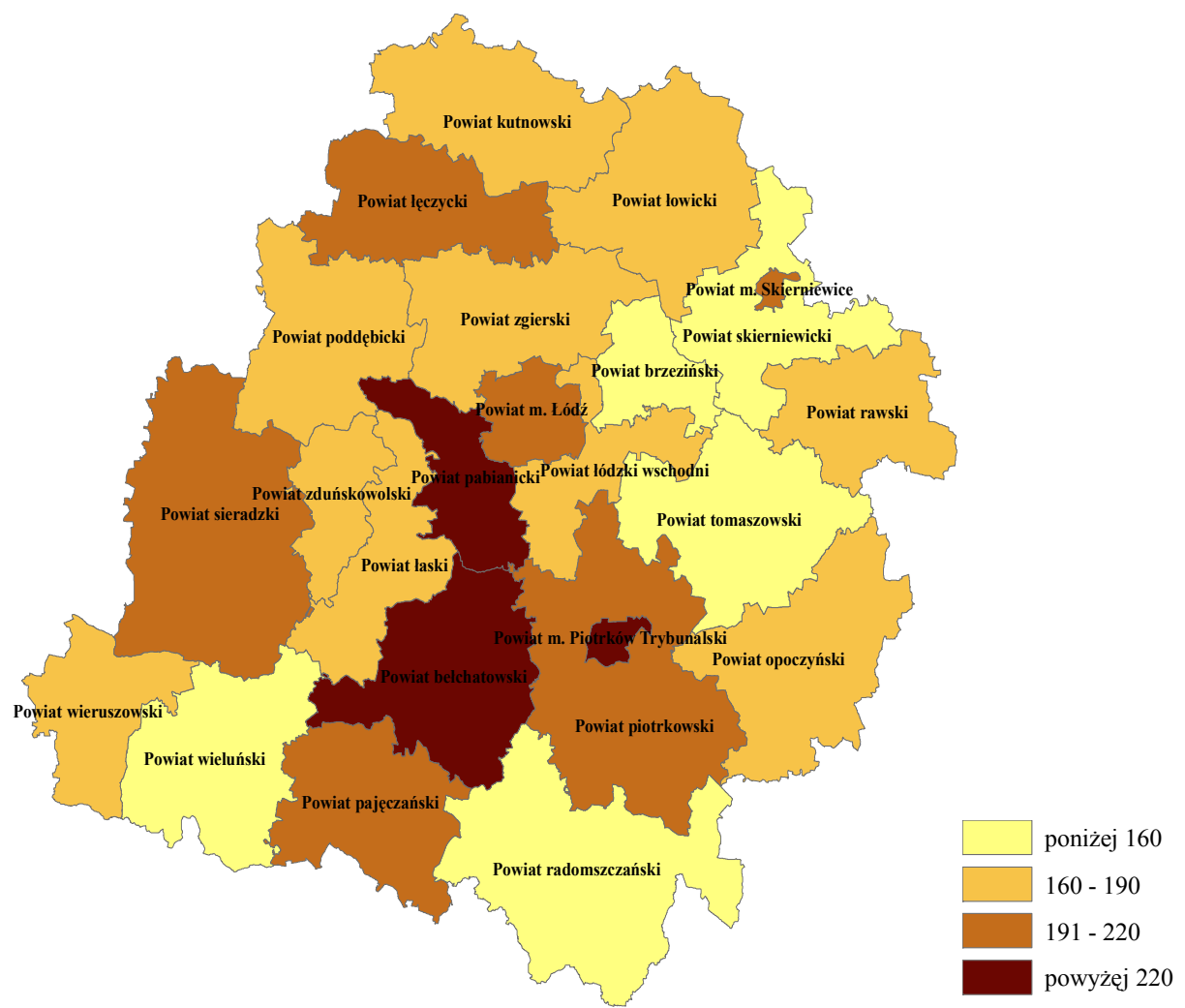

Źródło: Opracowanie własne na podstawie Systemu Informacji Oświatowej (SIO).

Badanie wielkości gimnazjów w województwie łódzkim pozwala stwierdzić, że największe jednostki tego typu znajdują się w powiatach bełchatowskim, pabianickim i Piotrkowie Trybunalskim, co podobnie jak w przypadku szkół podstawowych koreluje ze wskaźnikiem dostępności gimnazjów ze względu na obowiązek szkolny. W przypadku dwóch powiatów ziemskich wskaźnik przyjmuje wartość zbliżoną do 230 uczniów na jedno gimnazjum, natomiast w Piotrkowie Trybunalskim jego wartość przekracza 310 uczniów.

Do najmniej licznych gimnazjów zaliczają się placówki z terenu powiatu brzezińskiego, radomszczańskiego, skierniewickiego, tomaszowskiego i wieluńskiego. W przypadku tych placówek najmniejsza wartość wskaźnika notowana jest w powiecie skierniewickim i wynosi zaledwie 122 uczniów na gimnazjum. W pozostałych powiatach wartość ta waha się w przedziale od 145 do 159 uczniów. 
Analiza wartości średniej dla województwa pokazuje, że w przypadku gimnazjów publicznych notowany wskaźnik ma poziom 201 uczniów na gimnazjum. W przypadku szkół niepublicznych wartość ta wynosi tylko 69 uczniów. Pokazuje to, że w odniesieniu do średnich notowanych dla kraju (183 - gimnazja publiczne, 58 gimnazja niepubliczne), województwo łódzkie charakteryzuje się większymi placówkami, co może przekładać się na niższy poziom kształcenia, a tym samym mniejszą konkurencyjność kapitału ludzkiego w przyszłości.

Rysunek 9. Liczba uczniów przypadająca na jeden etat w gimnazjum

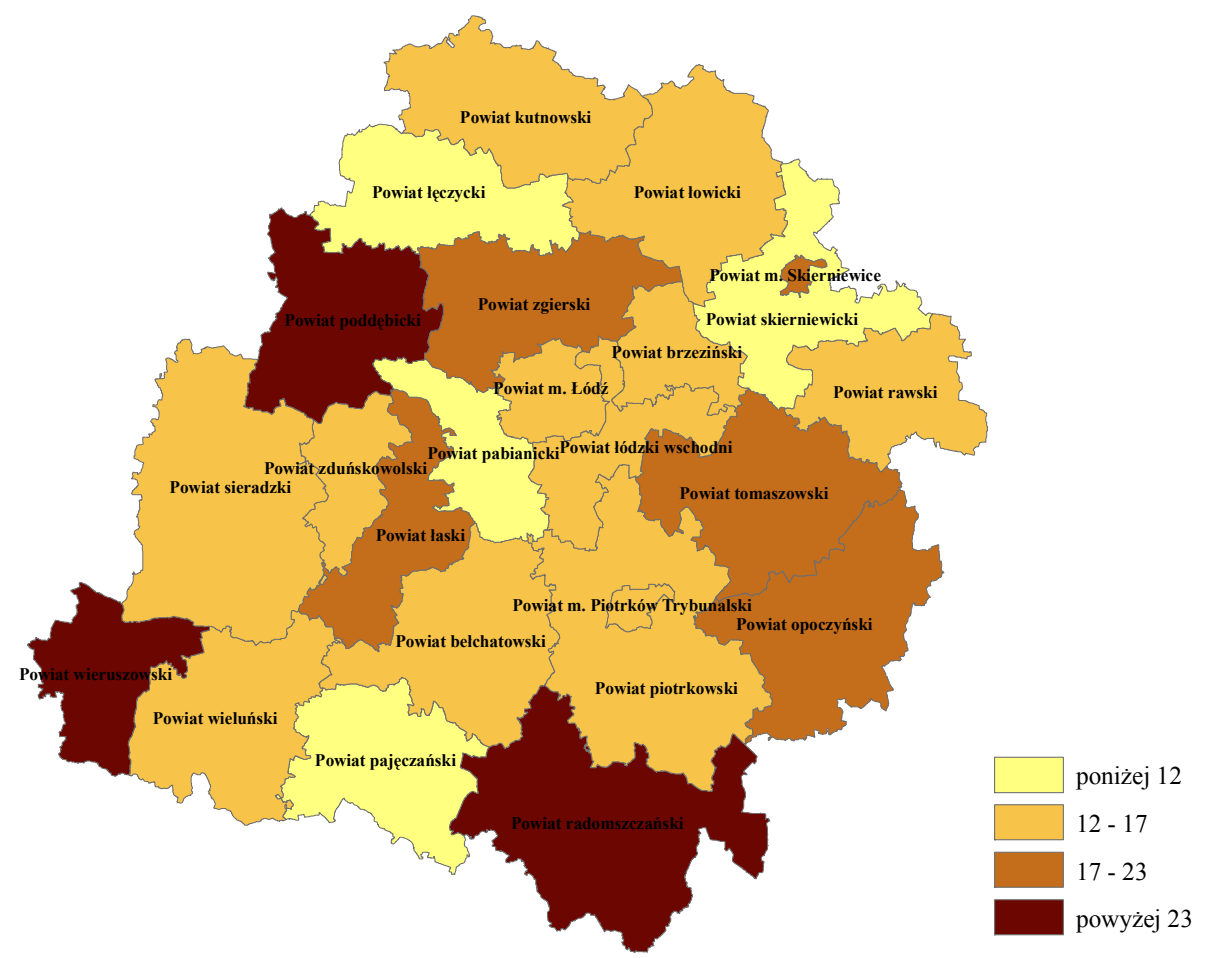

Źródło: Opracowanie własne na podstawie Systemu Informacji Oświatowej (SIO).

Badanie liczby uczniów przypadających na nauczyciela gimnazjum wykazało, że najlepsze warunki kształcenia posiadają uczniowie w powiatach: łęczyckim, pabianickim, pajęczańskim i skierniewickim, gdzie wartości omawianego wskaźnika były mniejsze niż 12 uczniów na nauczyciela. Najniższym wskaźnikiem odznaczał się powiat łęczycki, gdzie odnotowano niespełna 11 uczniów na nauczyciela w gimnazjum. Największe obciążenie nauczycieli zidentyfikowano w powiatach poddębickim, radomszczańskim i wieruszowskim. W przypadku 
tych powiatów wskaźnik wynosił więcej niż 23 uczniów na nauczyciela. Podkreślić jednak należy, że w powiecie poddębickim osiagną̧ on 29 uczniów.

W województwie łódzkim średnie obciążenie nauczycieli w gimnazjach wynosi 14 uczniów. Jeżeli rozpatrywany będzie podział na szkoły publiczne i niepubliczne to wskaźnik ten wyniesie odpowiednio 14 i 15 uczniów. Porównując wartości wskaźników do średnich notowanych dla kraju, uznać należy, że w przypadku szkół publicznych województwo łódzkie ma niższą wartość wskaźnika (średnia dla Polski 17 uczniów), natomiast w przypadku szkół niepublicznych wskaźnik osiąga wyższe wartości (średnia dla Polski 11 uczniów).

Ważnym elementem edukacji staje się motywacja uczniów do zajęć. Pogłębianie wiedzy oraz rozwój zdobytych umiejętności odbywać się może dzięki organizacji przez jednostki szkolne zajęć pozalekcyjnych. Dzięki tej formie zajęć organizowanej zarówno na poziomie szkół podstawowych, jak również gimnazjalnych możliwe jest rozwijanie indywidualnych umiejętności uczniów, co przekłada się na akumulację kapitału ludzkiego oraz rozwój jednostki.

Rysunek 10. Odsetek kół naukowych według rodzaju w szkołach podstawowych województwa łódzkiego (rok szkolny 2009/2010)

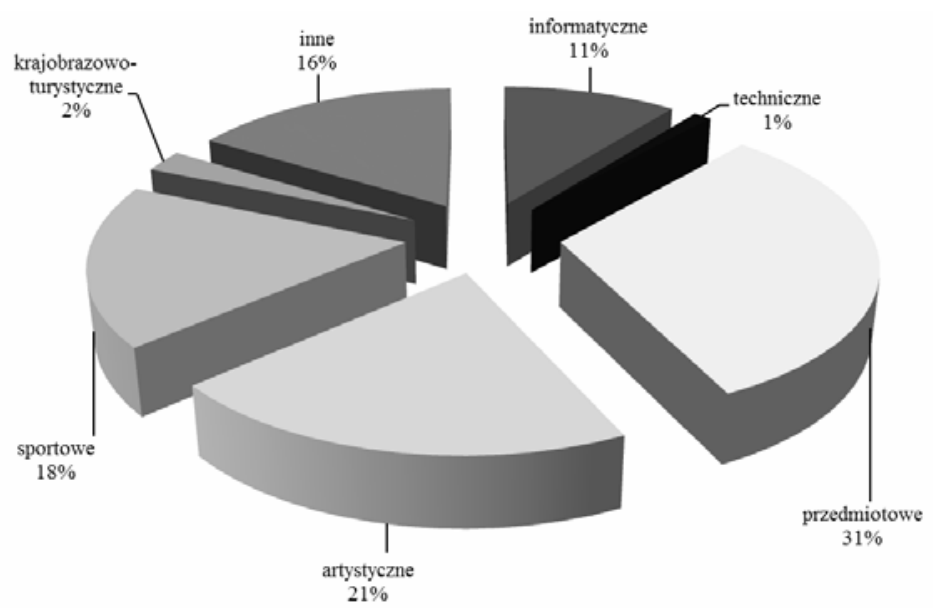

Źródło: Opracowanie własne na podstawie Oświata i wychowanie w roku szkolnym 2009/2010, GUS, Warszawa 2010.

Według zebranych danych, uczniowie szkół podstawowych biorący czynny udział w kołach naukowych i zajęciach pozaszkolnych, stanowili blisko $87 \%^{19}$

19 W przypadku wskaźnika należy przyjąć błąd związany z możliwością uczestnictwa uczniów w więcej niż jednym kole, bądź zajęciach pozaszkolnych. 
wszystkich dzieci uczęszczających do szkół podstawowych w województwie łódzkim. W przypadku tego samego wskaźnika dla Polski odnotowano poziom niespełna 77\% uczniów. Aktywność uczniów szkół podstawowych podczas zajęć pozaszkolnych rozwijana była w kołach przedmiotowych, czyli związanych z konkretnym przedmiotem nauczanym w szkole np. koła matematyczne, biologiczne, humanistyczne. Koła te stanowiły $31 \%$ wszystkich tego typu zajęć. Ważnym elementem rozwoju uczniów w szkołach podstawowych okazywały się być koła artystyczne (21\% ogółu kół), koła sportowe (18\%) oraz koła informatyczne $(11 \%)$. Mniejsze znaczenie na tym poziomie kształcenia okazywały się mieć koła krajobrazowo-turystyczne (2\%) i techniczne (1\%). Koła naukowe oraz ich rodzaj wskazują również na zainteresowania i potrzeby rozwoju uczniów szkół podstawowych. Struktura kół naukowych województwa łódzkiego odzwierciedla zjawisko zagregowane dla poziomu całego kraju.

Rysunek 11. Odsetek kół naukowych według rodzaju w gimnazjach województwa łódzkiego (rok szkolny 2009/2010)
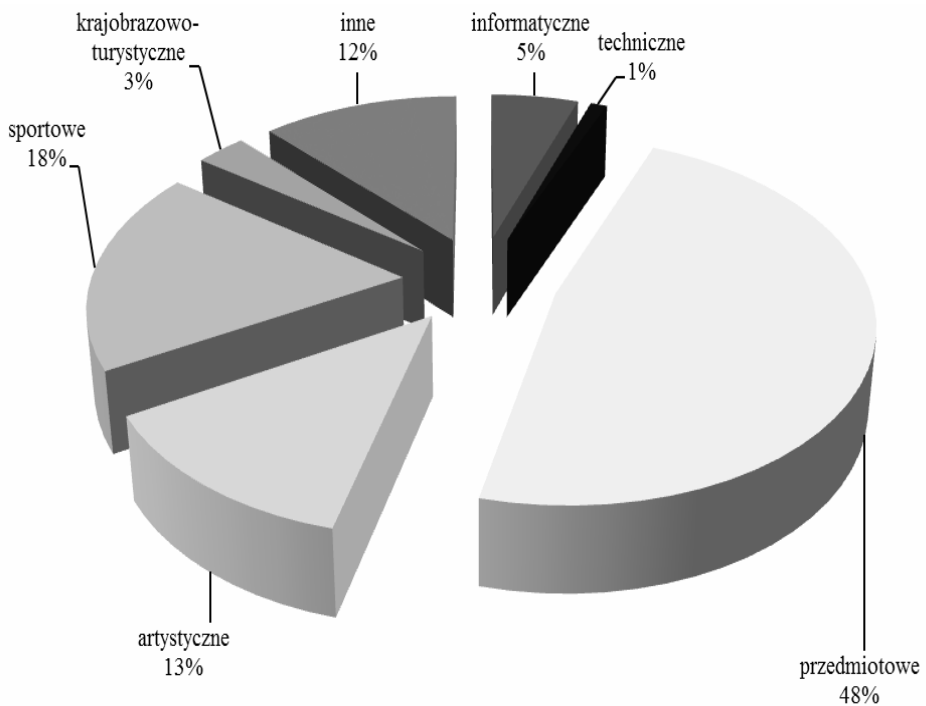

Źródło: Opracowanie własne na podstawie Oświata i wychowanie w roku szkolnym 2009/2010,GUS, Warszawa 2010.

Podobna analiza przeprowadzona została w przypadku gimnazjów. W kołach naukowych proponowanych uczniom gimnazjów w województwie łódzkim udział brało $81 \%{ }^{20}$ wychowanków. W przypadku Polski było to nieco ponad

${ }^{20} \mathrm{~W}$ przypadku wskaźnika należy przyjąć błąd związany z możliwością uczestnictwa uczniów w więcej niż jednym kole, bądź zajęciach pozaszkolnych. 
78\% uczniów. Uczniowie gimnazjów w województwie łódzkim mogli uczestniczyć w zajęciach pozalekcyjnych w kołach przedmiotowych, które stanowiły $48 \%$ wszystkich kół zlokalizowanych w tym typie szkół. Drugą co do wielkości grupą były zajęcia sportowe (18\% ogółu kół) oraz zajęcia artystyczne $(13 \%)$. W przypadku pozostałych kół, ich liczba była dużo mniejsza od wiodących zainteresowań. Koła informatyczne stanowiły $5 \%$ zajęć pozaszkolnych, koła krajobrazowo-turystyczne 3\%, a zajęcia techniczne zaledwie 1\%. Struktura kół naukowych w województwie łódzkim, podobnie jak w przypadku szkół podstawowych, odzwierciedlała strukturę zjawiska dla Polski. Istotne z punktu widzenia porównania dwóch stopni szkolnictwa jest wskazanie, że uczniowie gimnazjów mogą uczestniczyć częściej w zajęciach przedmiotowych, co odbywa się kosztem liczby kół artystycznych i informatycznych, które na poziomie gimnazjalnym mają mniejszy udział w strukturze zajęć pozaszkolnych.

\section{Dostępność systemu oświaty na poziomie ponadgimnazjalnym w województwie łódzkim}

System oświaty, w zakresie szkolnictwa ponadgimnazjalnego, pozwala uczniom na wybór różnych ścieżek rozwoju. Poczynając od nauki zawodu w szkołach zawodowych, technikach, liceach profilowanych, czy uzyskaniu wiedzy ogólnej w liceach ogólnokształcących. W przypadku młodzieży, która ukończyła gimnazjum powinna ona podjąć naukę w szkole ponadgimnazjalnej zgodnie z zapisem ustawy o obowiązku nauki do ukończenia 18 roku życia ${ }^{21}$.

Licea ogólnokształcące stanowią formę kształcenia ponadgimnazjalnego, która w województwie łódzkim wykazuje największą dostępność w miastach na prawach powiatów. W jednostkach tych zlokalizowane są ponad 4 licea na 1000 osób w wieku 16-18 lat. Podkreślić jednak należy, że największa liczba liceów mierzona tym wskaźnikiem zlokalizowana jest w Piotrkowie Trybunalskim i wynosi 7,3 placówki na 1000 osób wieku 16-18 lat.

Najmniejszą dostępnością liceów charakteryzują się powiaty: łódzki wschodni, łęczycki, pajęczański, poddębicki, wieluński i wieruszowski, gdzie liczba szkół jest mniejsza niż 2 na każde 1000 osób w wieku 16-18 lat. Najmniejszą dostępnością liceów charakteryzuje się powiat pajęczański, gdzie wskaźnik osiaga wartość niespełna 1.

Analiza pokazuje, że najmniej obciążonymi liceami ogólnokształcącymi dysponują powiaty: brzeziński, łódzki wschodni, piotrkowski i skierniewicki. Sugerować to może sytuację, w której młodzi mieszkańcy tych obszarów wybierają licea ogólnokształcące zlokalizowane w pobliskich miastach na prawach

${ }^{21}$ Artykuł 15 ustawy z dnia 7 września 1991 r. o systemie oświaty, Dz. U. $1991 \mathrm{Nr} 95$, poz. 425 , z późn. zmianami. 
powiatu. Najmniejsza wartość charakteryzuje powiat skierniewicki, gdzie notowana jest wielkość niespełna 57 uczniów na jedno liceum ogólnokształcące.

Rysunek 12. Liczba liceów ogólnokształcących na 1000 osób w wieku 16-18 lat

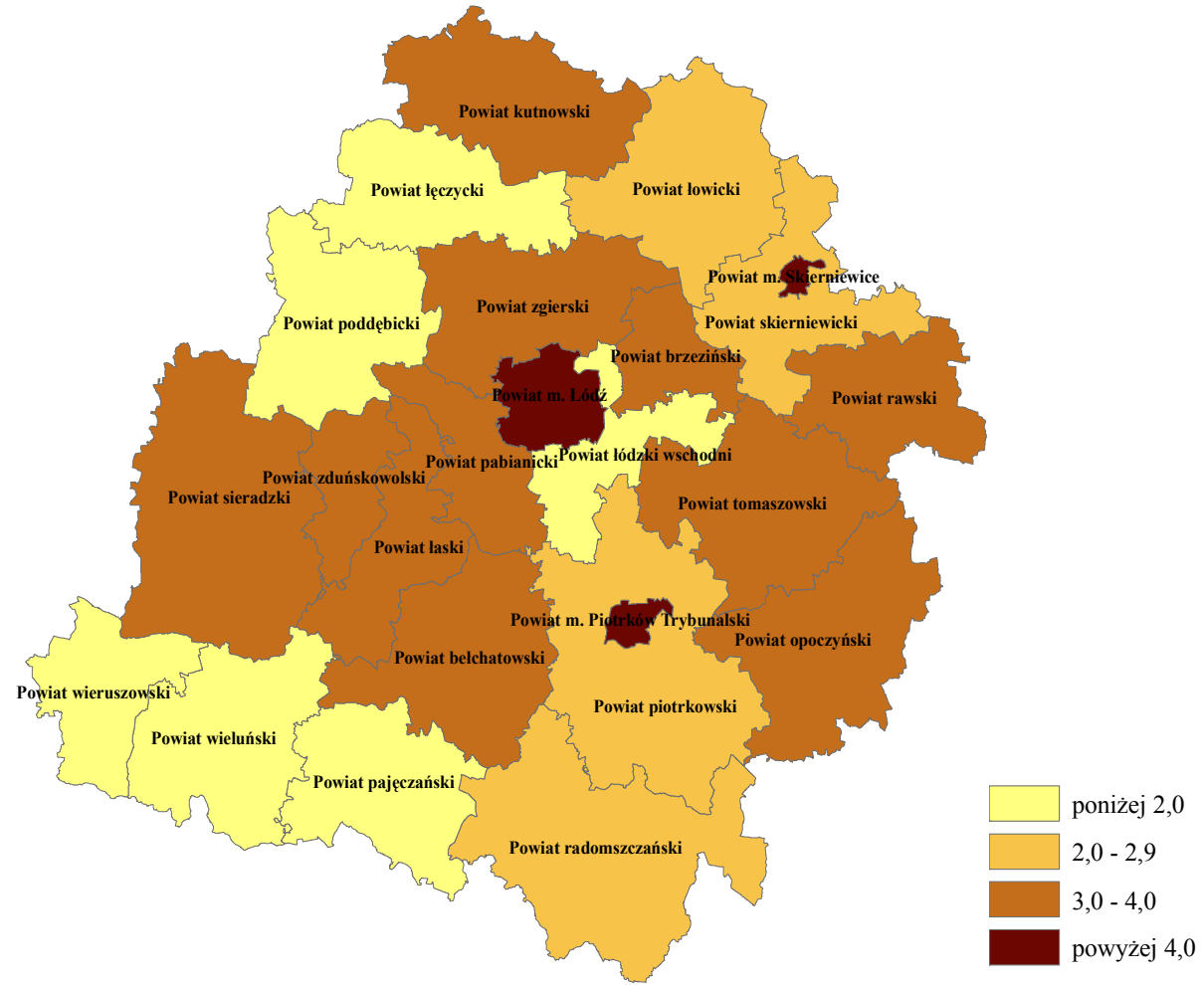

Źródło: Opracowanie własne na podstawie danych GUS i Systemu Informacji Oświatowej (SIO).

Licea o największej liczbie uczniów zidentyfikowane zostały w powiatach pajęczańskim i wieluńskim. Ich wielkość, mierzona liczbą uczniów, ponad dwukrotnie przekracza wartości notowane w jednostkach o najniższej średniej. W obu przypadkach wartość ta przekracza 270 uczniów na liceum. Średnia liczba uczniów przypadająca na liceum ogólnokształcące w województwie łódzkim wynosi 171 osób. Podział szkół na placówki publiczne i niepubliczne prowadzi do identyfikacji różnic, pomiędzy tymi jednostkami, gdzie odpowiednio notuje się wielkości wskaźnika na poziomie: 265 i 67 uczniów.

We wszystkich przypadkach są to wielkości niższe od średnich notowanych dla Polski, gdzie średnio w liceum kształci się 192 uczniów. W szkołach publicznych uczy się średnio 271 uczniów, a w niepublicznych 74. Najmniejsza liczba uczniów na jednego zatrudnionego w liceum ogólnokształcącym zidenty- 
fikowana została w powiatach: opoczyńskim, pajęczańskim, piotrkowskim i wieruszowskim, gdzie wskaźnik jest mniejszy od 12 uczniów na jednego zatrudnionego. Najmniejszą wartość notują licea ogólnokształcące w powiecie piotrkowskim (8 uczniów na zatrudnionego).

\section{Rysunek 13. Liczba uczniów przypadająca na jedno liceum ogólnokształcące}

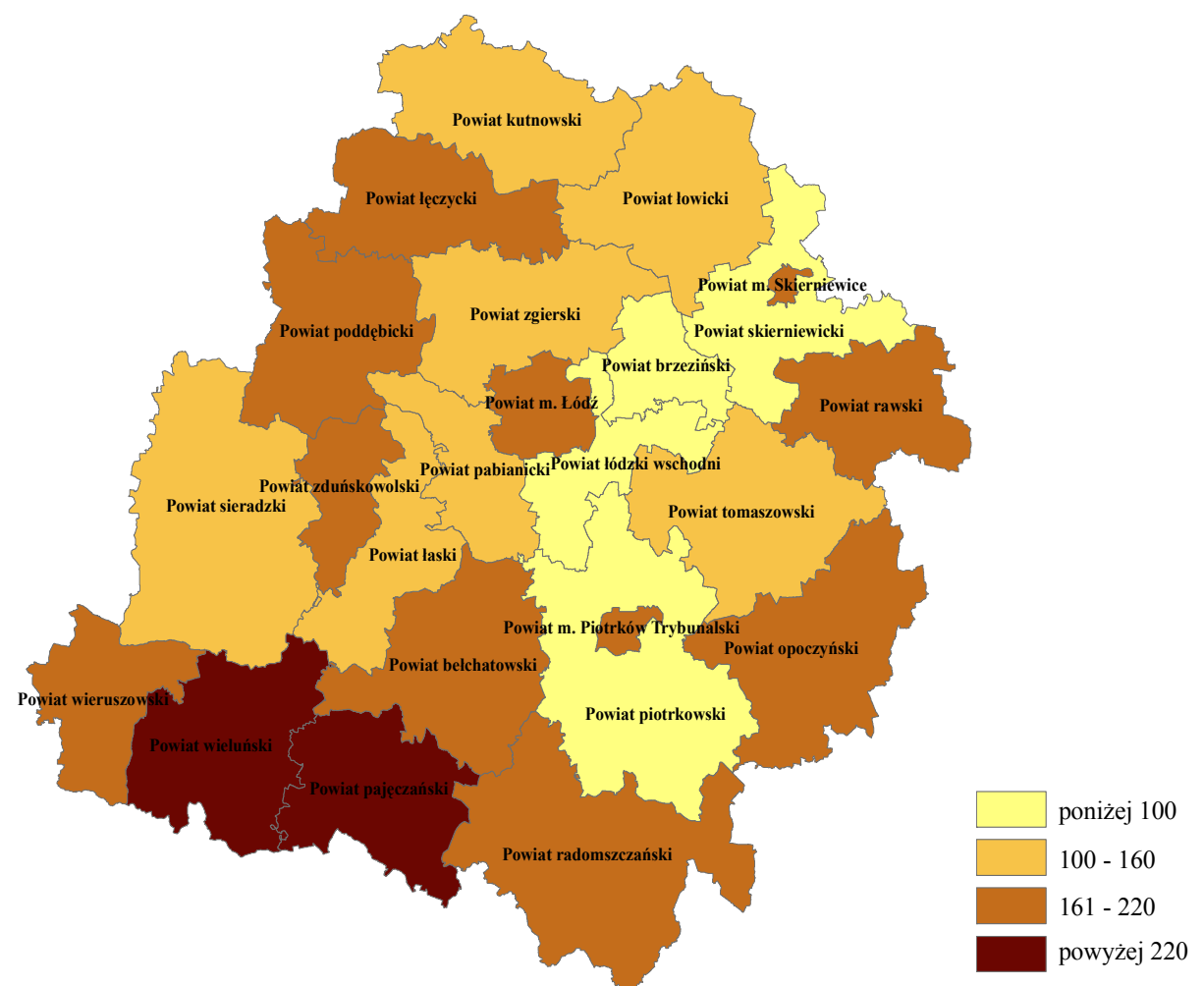

Źródło: Opracowanie własne na podstawie Systemu Informacji Oświatowej (SIO).

Największa liczba uczniów na zatrudnionego zidentyfikowana została w powiecie zgierskim i Skierniewicach. W obu przypadkach wskaźnik przekroczył wartość 30 uczniów na nauczyciela. Średnia wartość omawianego wskaźnika w województwie łódzkim wynosi 18 osób na nauczyciela. W przypadku szkół publicznych wskaźnik ten wynosi 17 uczniów, natomiast w placówkach niepublicznych 23 osoby. Odnosząc te dane do wartości wskaźnika notowanego w kraju należy stwierdzić, że średnio na nauczyciela liceum ogólnokształcącego przypada 27 uczniów (w szkołach publicznych jest to 28 uczniów, w niepublicznych 25), co pokazuje, że szkoły województwa łódzkiego notują niższe wartości. 
Podobnie jak w przypadku szkół zarządzanych przez samorząd gminny, w liceach ogólnokształcących prowadzone są zajęcia pozaszkolne. Brało w nich udział niespełna 44\% uczniów tych szkół. Jest to wynik niższy niż średni notowany dla kraju, gdzie wynosił on $49 \%$. Uczniowie liceów do wyboru mieli koła przedmiotowe, które stanowiły $60 \%$ wszystkich zajęć pozaszkolnych: koła sportowe $(15 \%)$ oraz artystyczne (7\%), informatyczne (5\%) oraz krajobrazowoturystyczne (2\%). Koła techniczne stanowiły udział poniżej $0,2 \%$ i nie odgrywały dużej roli w przypadku tego rodzaju szkół. Struktura rodzaju zajęć pozaszkolnych proponowana uczniom województwa łódzkiego pokrywa się ze strukturą zjawiska w kraju.

Rysunek 14. Liczba uczniów przypadająca na jeden etat w liceum ogólnokształcącym

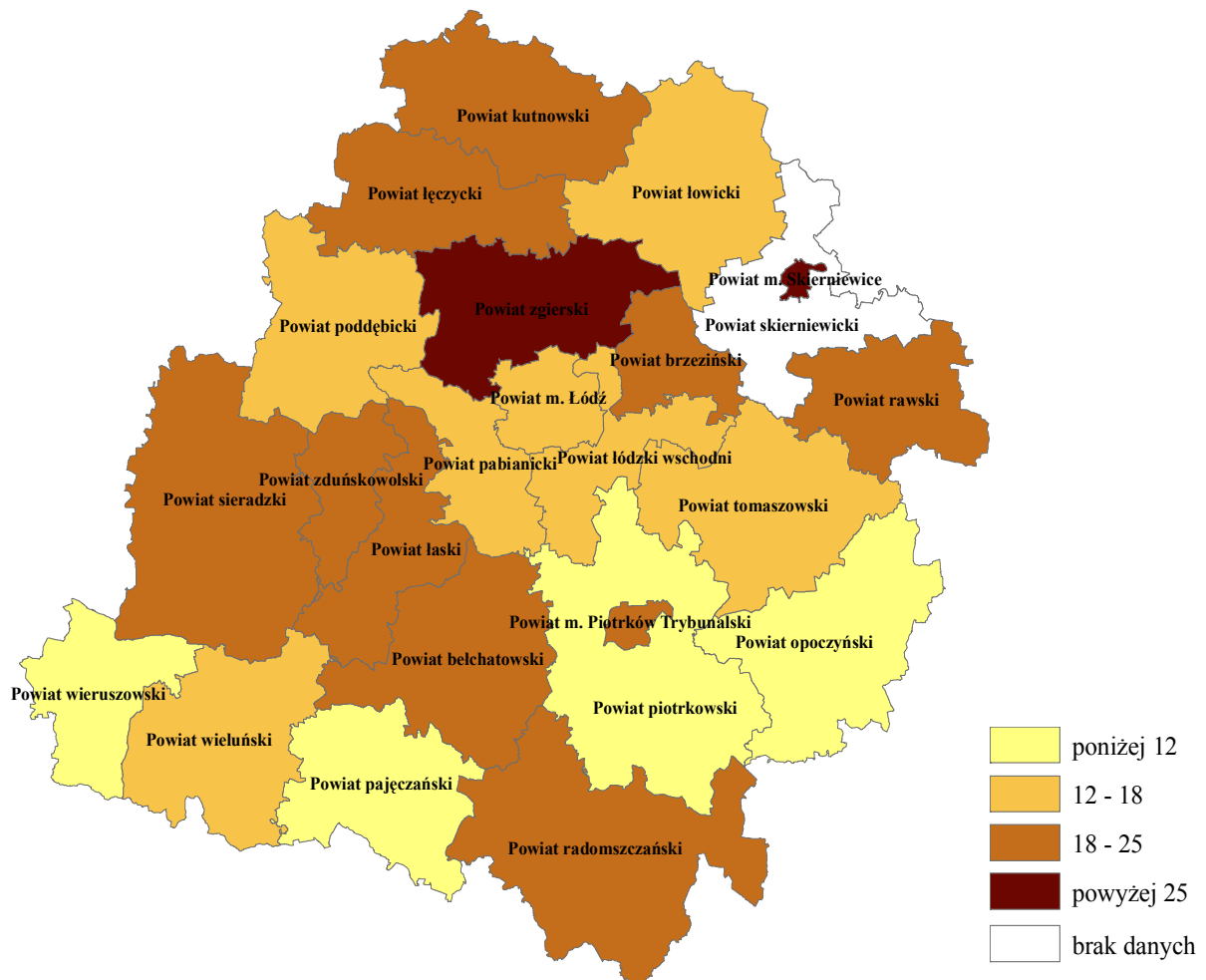

Źródło: Opracowanie własne na podstawie Systemu Informacji Oświatowej (SIO). 
Rysunek 15. Odsetek kół naukowych według rodzaju w liceach ogólnokształcących województwa łódzkiego (rok szkolny 2009/2010)

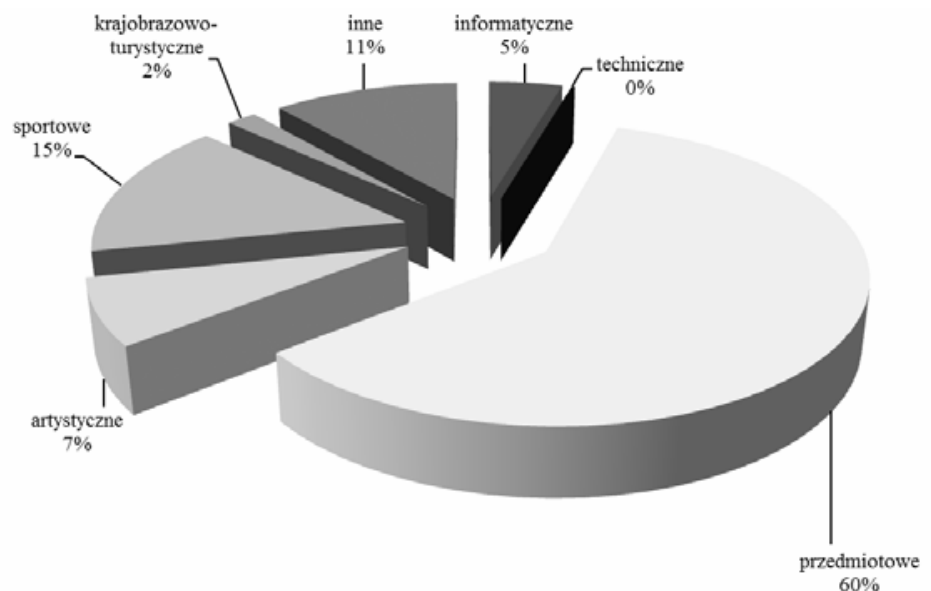

Źródło: Opracowanie własne na podstawie Oświata i wychowanie w roku szkolnym 2009/2010, GUS, Warszawa 2010.

Kolejnym sposobem realizacji obowiązku nauki jest skorzystanie $\mathrm{z}$ ofert techników, w których okres kształcenia trwa cztery lata i pozwala na przygotowanie do zawodu oraz otrzymanie świadectwa dojrzałości, co pozwala na dalsze kształcenie. Dostępność techników w poszczególnych powiatach województwa łódzkiego nie jest mocno zróżnicowana. Najmniejszą dostępnością tego rodzaju szkół ponadgimnazajalnych charakteryzują się powiaty ziemskie, wchodzące w skład Łódzkiego Obszaru Metropolitalnego (ŁOM) oraz powiaty: pajęczański, sieradzki i wieluński. Najmniejszymi wartościami wskaźnika liczby techników na 1000 osób w wieku 16-19 lat charakteryzują się powiaty: łódzki wschodni i brzeziński, gdzie wartość miary wynosi około 0,6. W przypadku powiatów okalających stolicę regionu, należy spodziewać się sytuacji, gdzie podaż na szkoły tego rodzaju pokrywana jest właśnie przez ofertę Łodzi.

Największą dostępnością charakteryzuje się miasto Piotrków Trybunalski, w którym wartość wskaźnika odbiega znacznie od pozostałych jednostek w województwie łódzkim i wynosi 2,9 techników na 1000 osób w wieku 16-19 lat. Powiatami, które wykazują się dobrą dostępnością techników dla uczniów, okazują się być również: łaski, rawski, skierniewicki oraz miasto Skierniewice. 
Rysunek 16. Liczba techników na 1000 osób w wieku 16-19 lat

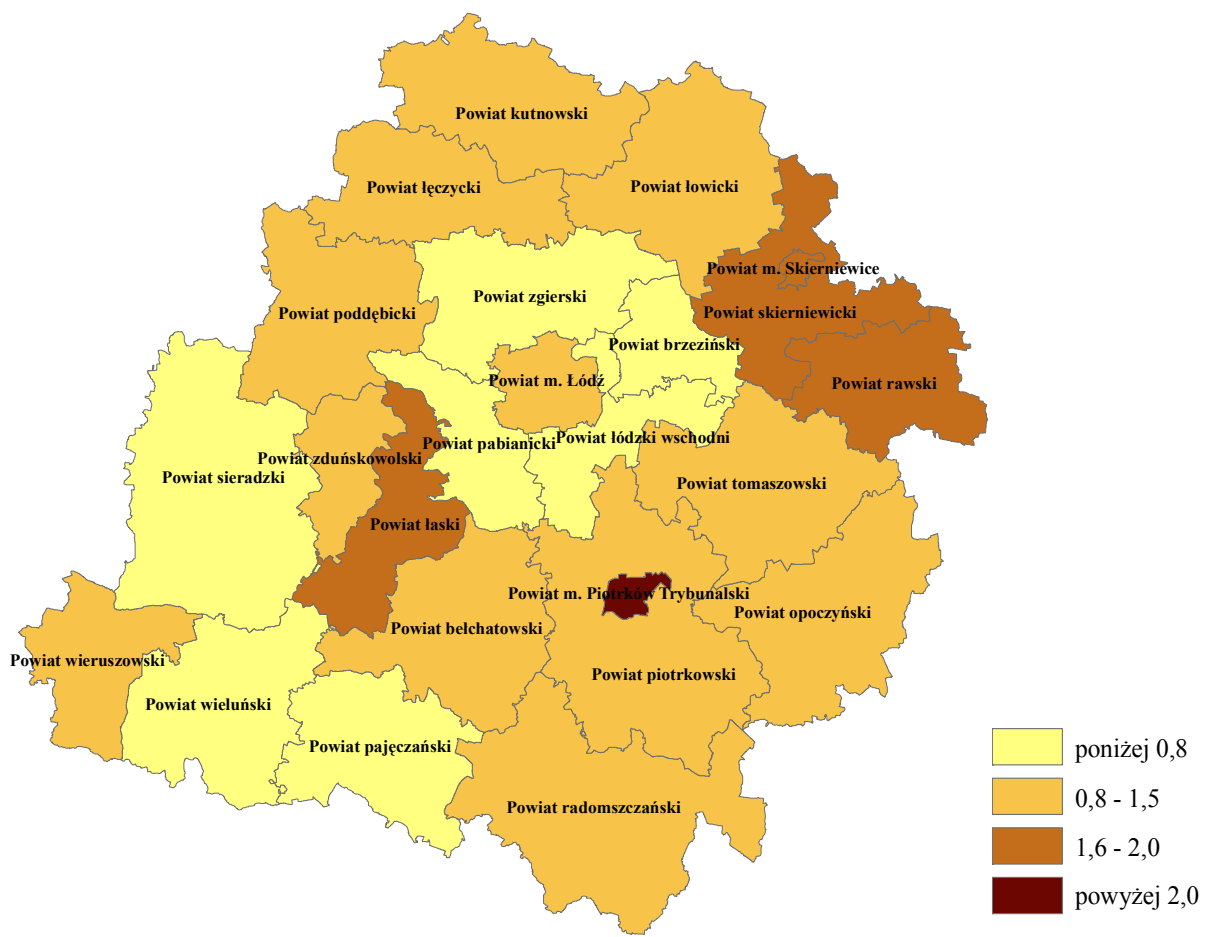

Źródło: Opracowanie własne na podstawie danych GUS i Systemu Informacji Oświatowej (SIO).

Dostępność techników koreluje się z liczbą uczniów przypadających na jedną szkołę tego typu jedynie w przypadku powiatów: łaskiego, skierniewickiego i wieluńskiego. To właśnie $\mathrm{w}$ powiecie łaskim, pajęczańskim, poddębickim i skierniewickim na jedno technikum przypada mniej niż 150 uczniów. W przypadku powiatu pajęczańskiego jest to zaledwie 74 uczniów na technikum.

Technika o największej liczbie uczniów zlokalizowane są w powiatach: tomaszowskim, wieluńskim i wieruszowskim. We wszystkich przypadkach stwierdzono tam średnio ponad 310 uczniów. Największą liczebnością techników wśród wymienionych charakteryzuje się powiat wieluński 393 uczniów na jedno technikum. Średnia wartość liczby uczniów przypadających na technikum w województwie łódzkim wynosi 228 osób. W przypadku szkół publicznych jest to 255 osób, natomiast do szkół niepublicznych uczęszcza średnio po 55 uczniów. Należy stwierdzić, że w przypadku szkół publicznych jest to wartość tożsama ze średnią notowaną w kraju. W szkołach niepublicznych kształci się w Polsce średnio 65 uczniów. 
Rysunek 17. Liczba uczniów przypadająca na jedno technikum

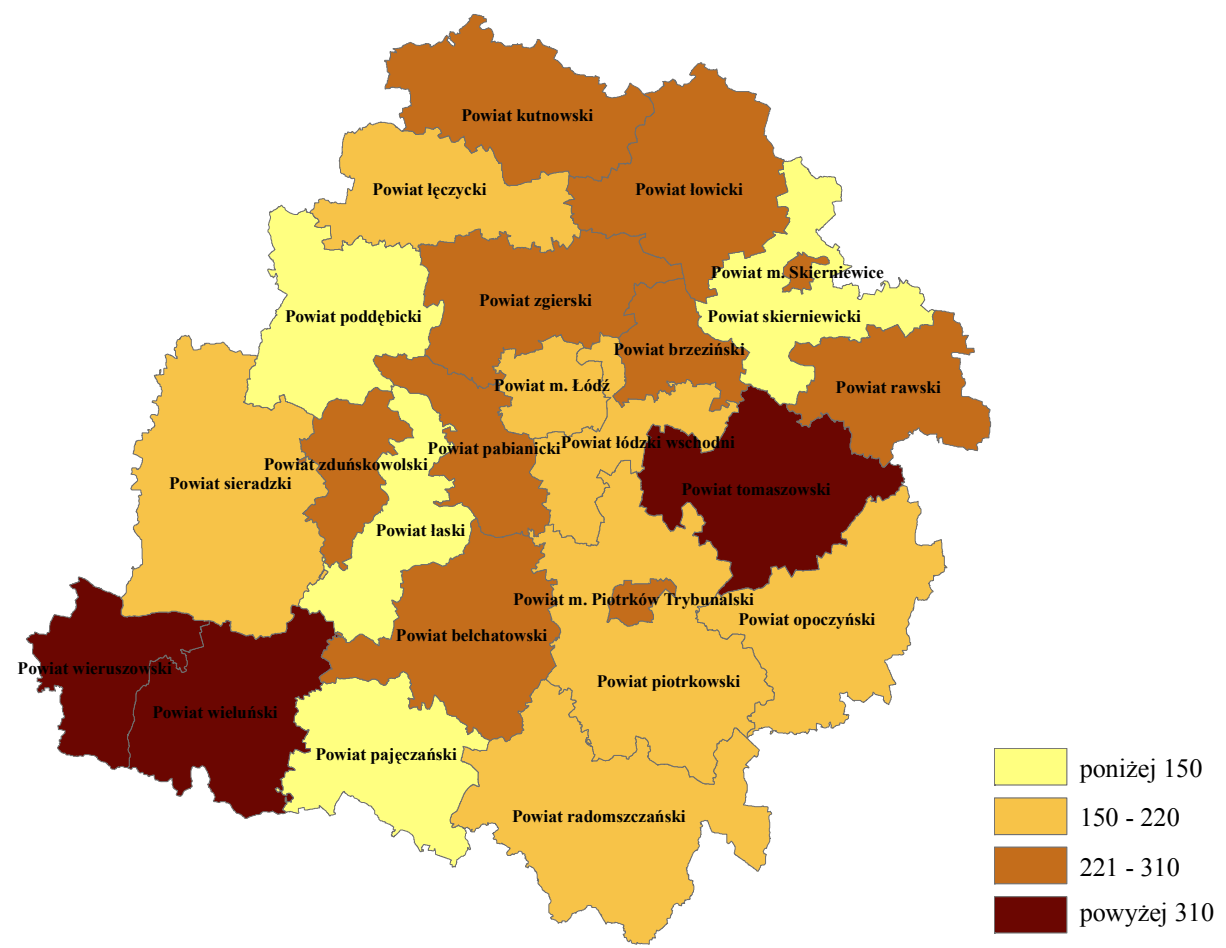

Źródło: Opracowanie własne na podstawie Systemu Informacji Oświatowej (SIO).

Jeśli chodzi o możliwość rozwoju uczniów techników na zajęciach pozaszkolnych, dostępnych jest 1000 kół naukowych. Uczestnikami zajęć jest ponad $43 \%$ uczniów techników. W przypadku kraju jest to niespełna $41 \%$ uczniów tego rodzaju szkół. W województwie łódzkim znajduje odzwierciedlenie krajowa struktura kół naukowych z uwzględnieniem ich tematyki. Największa liczba zajęć pozaszkolnych odbywa się w kołach przedmiotowych (47\% kół). Kolejnymi pod względem liczebności są koła sportowe (15\%), informatyczne $(9 \%)$, techniczne i artystyczne (po 6\%) oraz krajobrazowo - turystyczne (3\%). W przypadku omawianego rodzaju szkół należało przypuszczać, że większe znaczenie mogą mieć koła techniczne oraz informatyczne, jednak ich liczba nie zaskakuje. W przypadku kół informatycznych jest wyższa o 2 p. p. od średniej wyliczonej dla kraju. 
Rysunek 18. Odsetek kół naukowych według rodzaju w technikach województwa łódzkiego (rok szkolny 2009/2010)

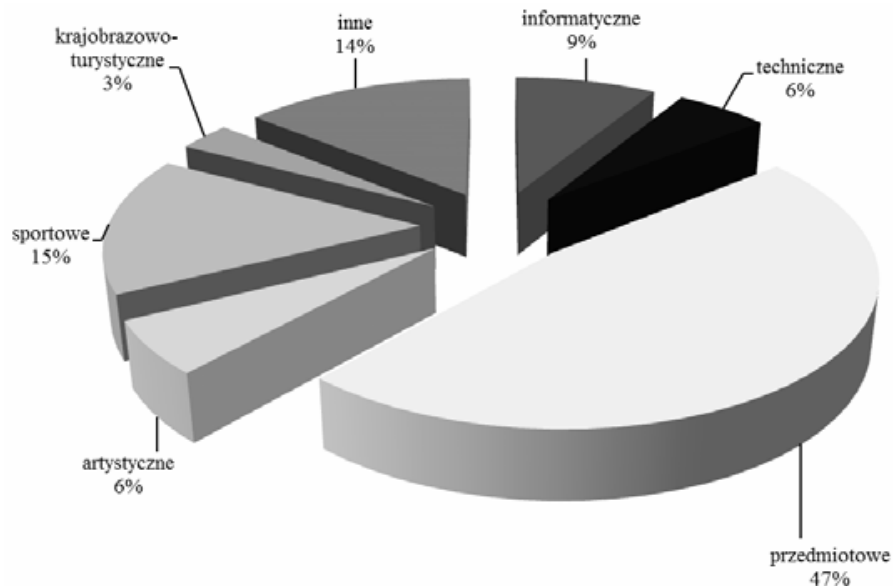

Źródło: Opracowanie własne na podstawie Oświata i wychowanie w roku szkolnym 2009/2010, GUS, Warszawa 2010.

Kształcenie ogólnozawodowe zapewnione jest w polskim systemie oświaty przez licea profilowane, których ukończenie umożliwia złożenie egzaminu dojrzałości. Analiza dostępności tego rodzaju szkół pozwala stwierdzić, że w czterech powiatach województwa łódzkiego nie jest zlokalizowane żadne liceum profilowane, są to powiaty: brzeziński, łaski, łowicki i piotrkowski. Najniższą dostępność, jeśli chodzi o powiaty, w których zidentyfikowano omawiane placówki, notują powiaty: łódzki wschodni i sieradzki. Wskaźnik w tych powiatach osiąga wartość 0,4 szkoły na 1000 osób w wieku 16-18 lat.

Najwyższą dostępnością szkół charakteryzują się powiaty: kutnowski, łęczycki, opoczyński, skierniewicki i zduńskowolski. W przypadku łęczyckiego i zduńskowolskiego liczba liceów profilowanych na 1000 osób w wieku 16-18 lat osiaga wartość 1,5 , co jest najwyższą wartością. Dość dobrą dostępność liceów profilowanych wykazują wszystkie miasta na prawach powiatów oraz powiaty: rawski, wieruszowski i zgierski.

W przypadku powiatów nieposiadających liceów profilowanych należy przyznać, że we wszystkich przypadkach graniczą one z powiatami o najwyższym wskaźniku w województwie. Sytuacja ta pozwalać może na pokrycie popytu na potrzeby szkolne uczniów z tych jednostek terytorialnych. 
Rysunek 19. Liczba liceów profilowanych na 1000 osób w wieku 16-18 lat

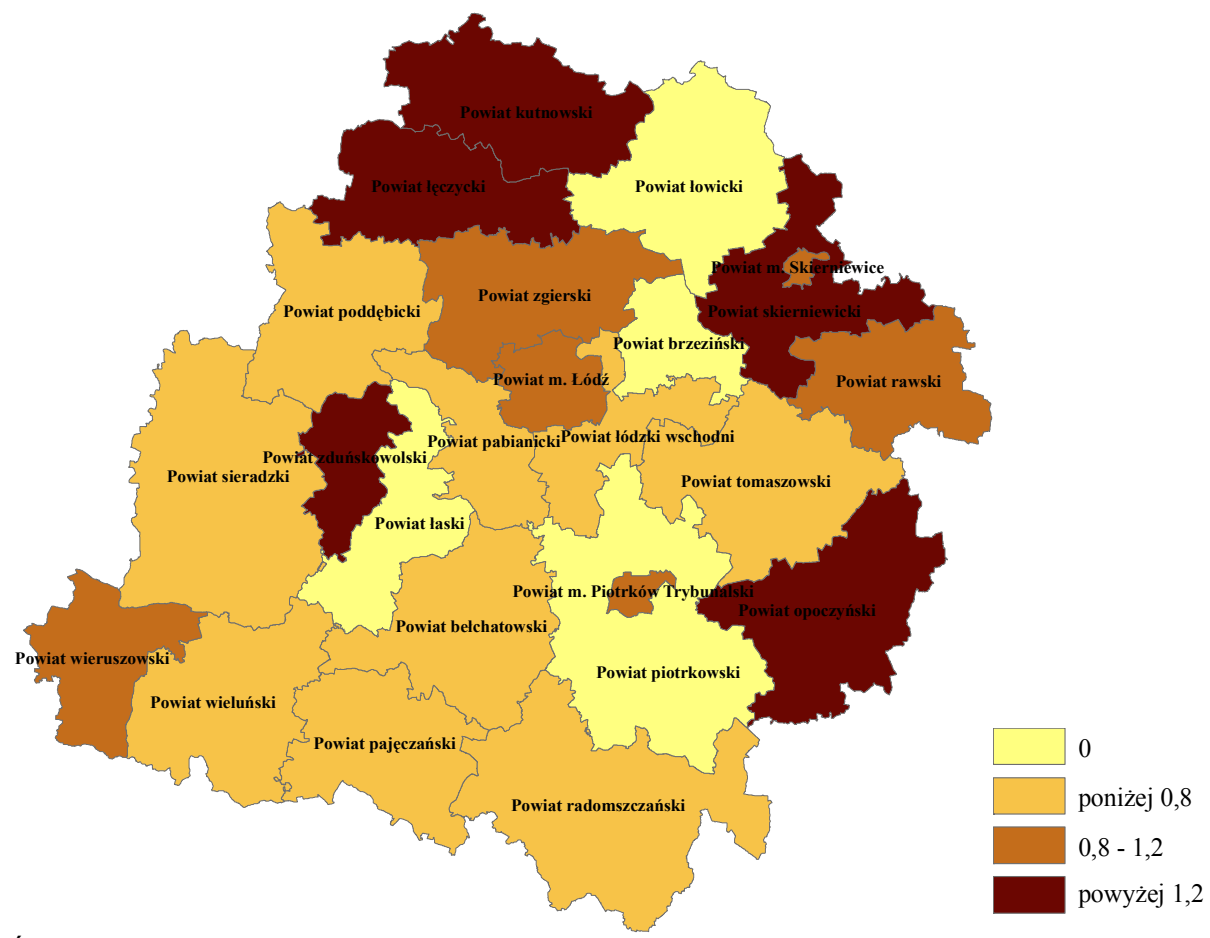

Źródło: Opracowanie własne na podstawie danych GUS i Systemu Informacji Oświatowej (SIO).

Liczba uczniów uczęszczających do liceów profilowanych pozwala stwierdzić, że mimo dobrej dostępności szkół w powiatach: pajęczańskim, skierniewickim i tomaszowskim, do placówek tych nie uczęszczał w roku szkolnym 2010/2011 żaden uczeń. Świadczy to również o tym, że w ostatnich trzech latach szkoły te w wymienionych powiatach nie cieszyły się zainteresowaniem. Wskaźnikiem na poziomie poniżej 45 uczniów na szkołę charakteryzują się Piotrków Trybunalski i Skierniewice oraz powiaty ziemskie: opoczyński, rawski, wieruszowski, zduńskowolski i zgierski. W przypadku powiatów: zduńskowolskiego i opoczyńskiego jest to wynik dobrej dostępności tego rodzaju placówek w wymienionych jednostkach terytorialnych.

Najliczniejsze licea profilowane zidentyfikowane zostały w powiatach: pabianickim, poddębickim, radomszczańskim i sieradzkim. Średnia liczba uczniów w szkołach przekracza tam 90 osób. Największe placówki pod względem liczby uczniów zlokalizowane są w powiecie poddębickim, gdzie wartość wskaźnika osiagga 129 osób. 
Średnio liceum profilowane w województwie łódzkim posiada 55 uczniów. Co ciekawe znacznie większe są placówki niepubliczne. W przypadku województwa łódzkiego szkoły publiczne notują wskaźnik na poziomie 49 uczniów na szkołę, przy 108 uczniach w liceach niepublicznych. Odnosząc zjawisko do całego kraju, średnia liczebność liceum profilowanego wynosi 44 uczniów. Różnicując to na placówki publiczne i niepubliczne wskaźnik ma wartość odpowiednio: 41 i 73 uczniów.

Rysunek 20. Liczba uczniów przypadająca na jedno liceum profilowane

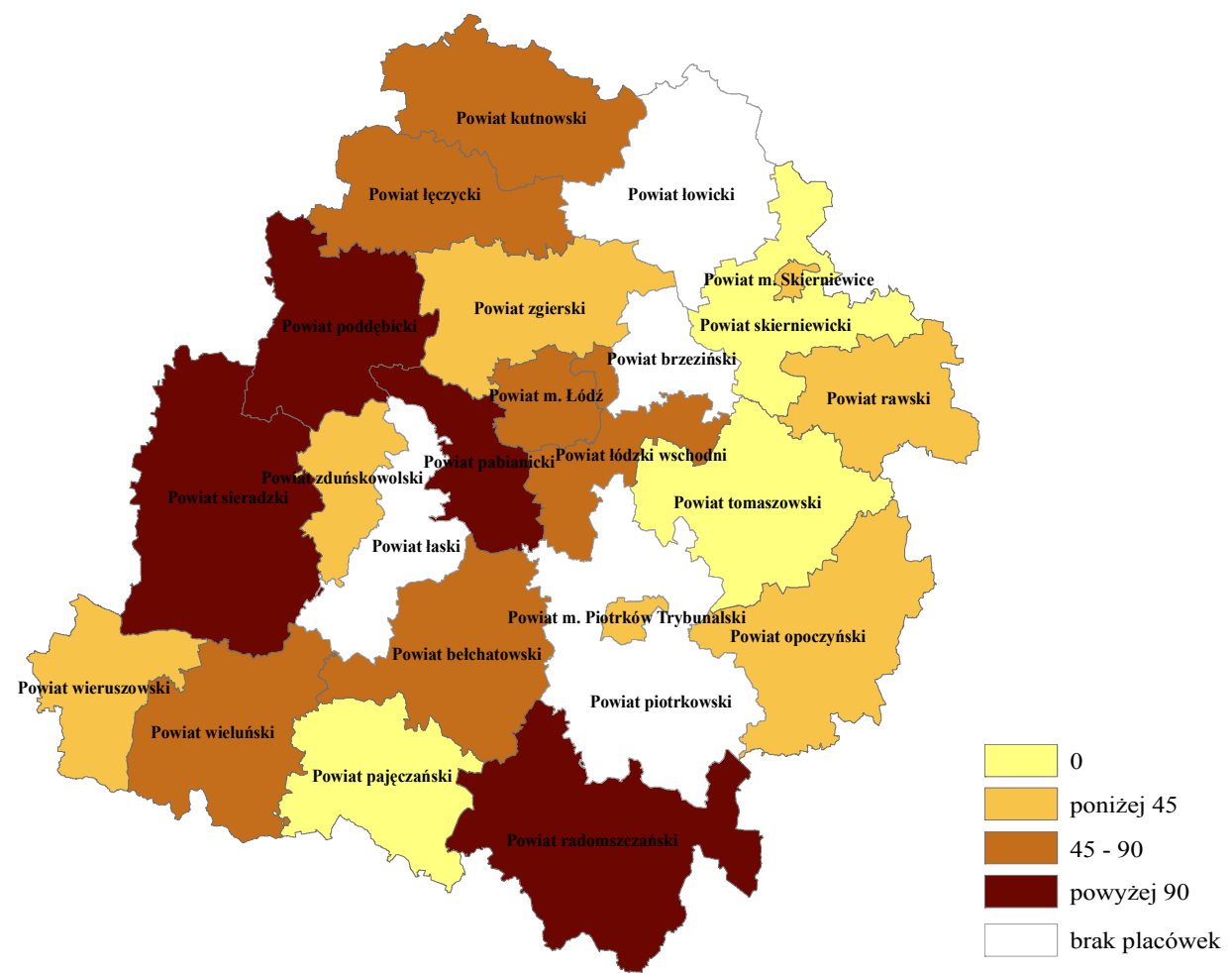

Źródło: Opracowanie własne na podstawie Systemu Informacji Oświatowej (SIO).

W województwie łódzkim zaangażowanie w zajęcia pozaszkolne wykazało blisko 54\% uczniów liceów profilowanych. Wskaźnik ten jest niższy od notowanego w Polsce, gdzie wynosi on ponad $61 \%$. Uczniowie liceów mogli uczestniczyć w zajęciach przedmiotowych, które stanowiły 50\% wszystkich zajęć. Wysokie miejsce w strukturze zajęć pozaszkolnych zajmowały zajęcia sportowe $(17 \%)$ oraz informatyczne $(10 \%)$. W liceach profilowanych uczniowie moga 
również uczęszczać do kół artystycznych (8\%), krajobrazowo-turystycznych $(2 \%)$ oraz technicznych $(1 \%)$.

Rysunek 21. Odsetek kół naukowych według rodzaju w liceach profilowanych województwa łódzkiego (rok szkolny 2009/2010)

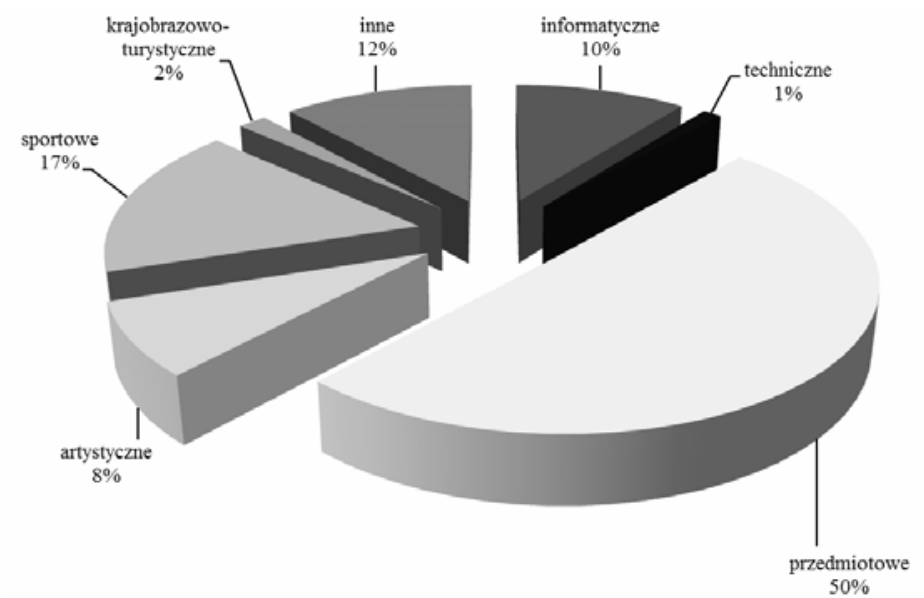

Źródło: Opracowanie własne na podstawie Oświata i wychowanie w roku szkolnym 2009/2010, GUS, Warszawa 2010.

Kolejnym ogniwem w szkolnictwie są zasadnicze szkoły zawodowe. Kształcą one w zakresie zawodów określonych profilem szkoły. Okres nauki w tego typu szkołach trwa od 2 do 3 lat. W ostatnim czasie województwo łódzkie wspiera rozwój tych szkół. Realizowana jest kampania „Zawodowo dla Łodzi”, której zadaniem jest promowanie szkół zawodowych i technicznych. W akcje zaangażowany jest Urząd Wojewódzki w Łodzi oraz pracodawcy, których firmy zlokalizowane są na terenie województwa łódzkiego. Podjęta akcja ma na celu wskazanie, że szkoły zawodowe i techniczne pozwalają na rozwój ścieżki zawodowej oraz umożliwiają znalezienie pracy już po szkole ponadgimnazjalnej.

Dostępność zasadniczych szkół zawodowych w województwie łódzkim wykazuje, że w powiecie skierniewickim nie ma żadnej szkoły tego typu, co może być podyktowane wysoką dostępnością, „zawodówek” w samych Skierniewicach. Podobną sytuację można zaobserwować w relacji powiat piotrkowski i miasto Piotrków Trybunalski. Dostępnością poniżej 0,8 szkoły na 1000 osób w wieku 16-18 lat charakteryzują się powiaty: łódzki wschodni, piotrkowski i poddębicki. Najmniejszą dostępność zidentyfikowano w powiecie łódzkim wschodnim tj. 0,4 szkoły na 1000 osób w wieku 16-18 lat. 
Rysunek 22. Liczba zasadniczych szkół zawodowych na 1000 osób w wieku 16-18 lat

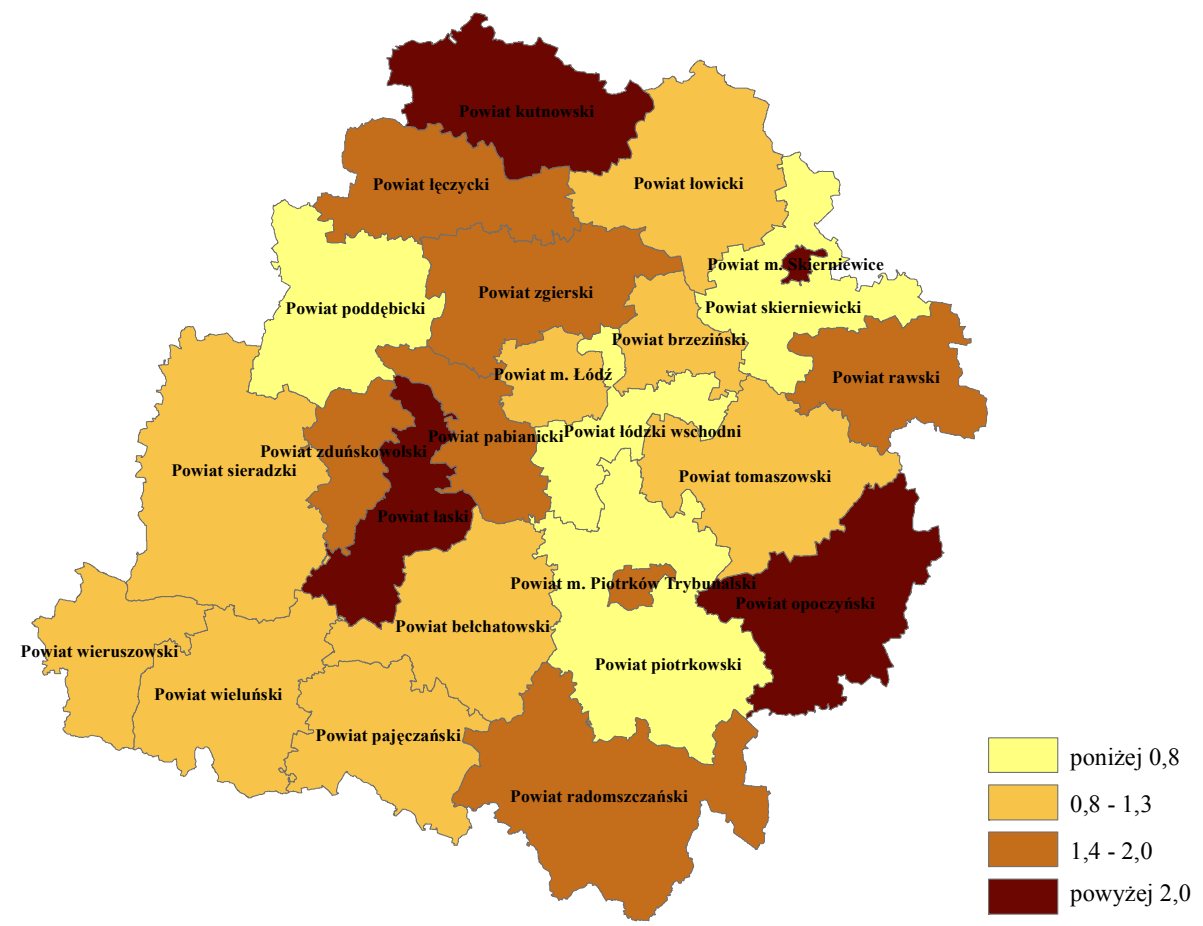

Źródło: Opracowanie własne na podstawie danych GUS i Systemu Informacji Oświatowej (SIO).

Najwyższą dostępnością zasadniczych szkół zawodowych charakteryzują się powiaty: kutnowski, łaski, opoczyński i miasto Skierniewice. We wszystkich jednostkach lokalnych poziom wskaźnika przekracza wartość 2 , najwyższą wartość osiaga zaś $\mathrm{w}$ powiecie łaskim 2,5 . W przypadku powiatów ziemskich o dużej dostępności zasadniczych szkół zawodowych, koresponduje to z dostępnością szkół technicznych w tych powiatach.

Wielkość szkół zawodowych wskazuje, że w powiecie brzezińskim, piotrkowskim i zgierskim szkoły mają najmniejszą liczebnośćc ${ }^{22}$. Najmniejsze szkoły zawodowe pod względem liczby uczniów zidentyfikowano w powiecie piotrkowskim, gdzie średnia wielkość tych jednostek wynosi 45 uczniów. Największym obłożeniem w szkołach zawodowych charakteryzują się powiaty: poddębicki, wieluński, wieruszowski oraz miasto Piotrków Trybunalski. W przypadku tych jednostek najwyższe wartości wskaźnika, przekraczające 200 uczniów na szkołę notowane są w ,zawodówkach” powiatów: wieluńskiego i wieruszowskiego.

\footnotetext{
${ }^{22}$ Nie jest analizowany powiat skierniewicki, w którym nie zlokalizowano żadnej zasadniczej szkoły zawodowej.
} 
Rysunek 23. Liczba uczniów przypadająca na jedną zasadniczą szkołę zawodową

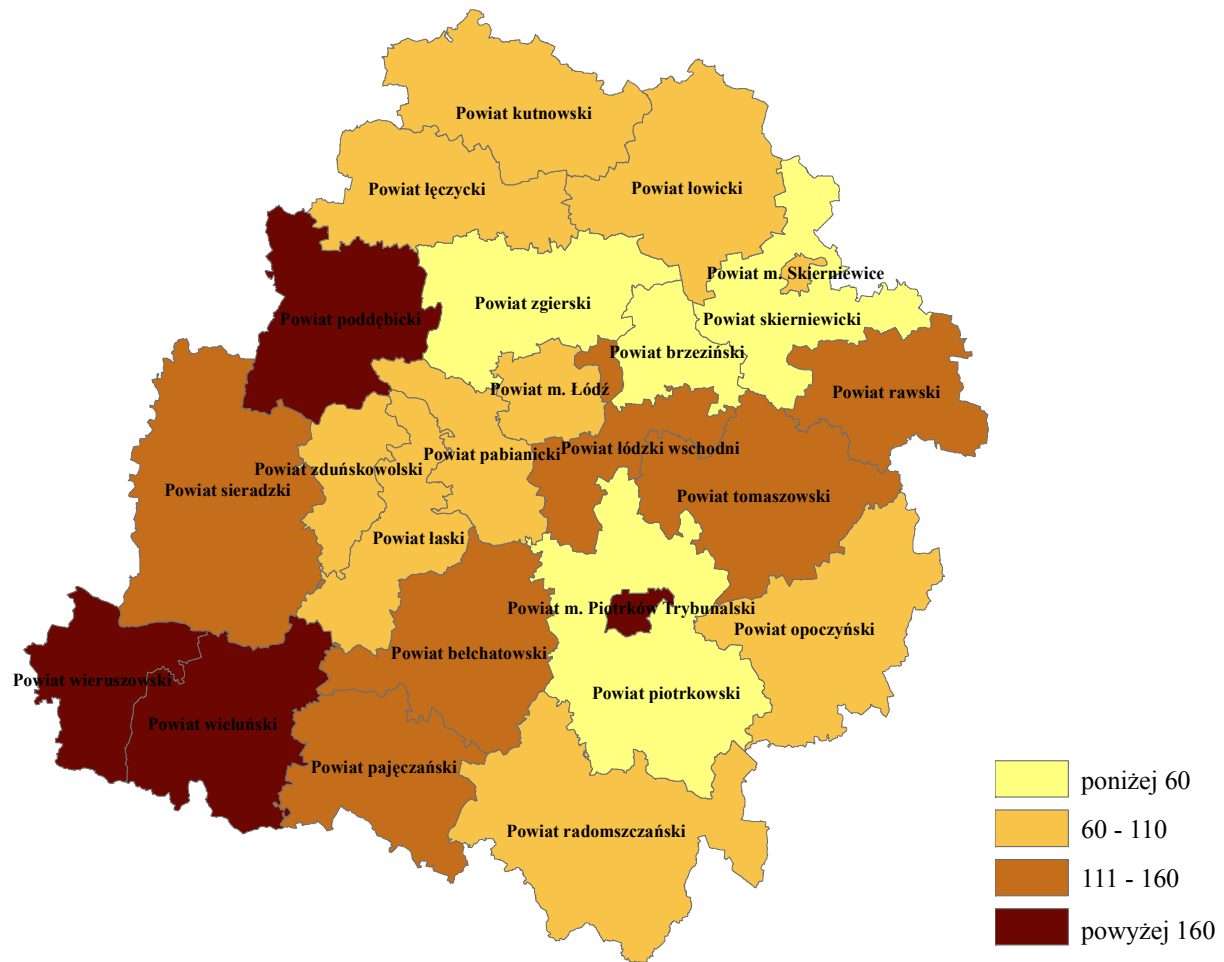

Źródło: Opracowanie własne na podstawie Systemu Informacji Oświatowej (SIO).

Średnie wartości wskaźnika liczby uczniów na szkołę zawodową w województwie łódzkim wynoszą 98 osób. Przy uwzględnieniu rodzaju placówki ze względu na jej publiczność i niepubliczność, wskaźnik osiaga odpowiednio wartości: 103 i 47 . We wszystkich przypadkach są to wartości niższe od średnich notowanych dla Polski i wynoszących: 113 dla ogółu placówek, 117 dla szkół publicznych i 66 dla szkół niepublicznych.

Jeżeli chodzi o możliwość rozwoju podczas zajęć pozaszkolnych to uczestnictwo w nich deklarowało 20\% uczniów zasadniczych szkół zawodowych w województwie łódzkim. Deklarację taką w skali kraju złożyło 19\% uczniów. W przypadku zasadniczych szkół zawodowych największa jest liczba zajęć pozaszkolnych o charakterze sportowym (29\%). Nieco mniejsza jest liczba kół przedmiotowych (22\%). Pozaszkolne zajęcia techniczne i informatyczne stanowią odpowiednio: $12 \%$ i $10 \%$ wszystkich tego typu zajęć. Uczniowie mogą również uczestniczyć w zajęciach artystycznych (7\%) oraz krajobrazowoturystycznych $(5 \%)$. 
Rysunek 24. Odsetek kół naukowych według rodzaju w zasadniczych szkołach zawodowych województwa łódzkiego (rok szkolny 2009/2010)

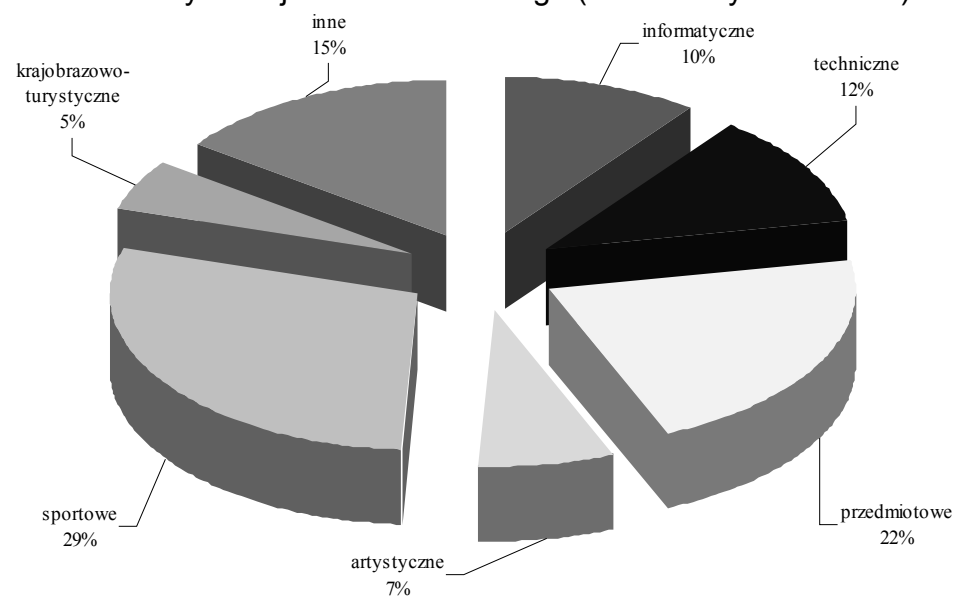

Źródło: Opracowanie własne na podstawie Oświata i wychowanie w roku szkolnym 2009/2010, GUS, Warszawa 2010.

Kontynuacja nauki i podnoszenie kompetencji po zakończeniu edukacji w zasadniczej szkole zawodowej może mieć miejsce w liceach bądź technikach uzupełniających. Kształcenie w uzupełniających liceach trwa dwa lata i kończy się przystapieniem do egzaminu dojrzałości. Dostępność tego typu jednostek w województwie łódzkim najmniejsza jest w powiatach: łaskim, pajęczańskim i poddębickim. Najniższą wartość wskaźnika notuje powiat pajęczański, 0,7 liceum na 1000 osób w wieku 19-20 lat. Najwyższą zaś dostępnością odznaczają się natomiast powiat zduńskowolski i Piotrków Trybunalski. W przypadku miasta na prawach powiatu wskaźnik wynosi 4,3 szkoły na 1000 osób w wieku 19-20 lat.

Najmniej liczne licea znajdują się w powiatach: brzezińskim, łaskim, łęczyckim, skierniewickim i zgierskim. We wszystkich przypadkach średnia wielkość szkoły tego typu w powiecie nie przekracza 20 uczniów. Powiaty: łaski i skierniewicki, pomimo że posiadają licea uzupełniające, wykazują zerową liczbę uczniów w tych jednostkach. Najmniejsze są szkoły w powiecie brzezińskim, gdzie liczba uczniów wyniosła 16. Analiza wielkości uzupełniających liceów ogólnokształcących w województwie nasuwa wniosek, że popyt na szkoły tego typu w powiatach: łaskim i skierniewickim pokrywany jest przez powiaty sąsiednie, chociażby przez powiat zduńskowolski (w przypadku powiatu łaskiego) oraz przez miasto Skierniewice (w przypadku powiatu skierniewickiego), gdzie dostępność uzupełniających liceów była jedną z wyższych. Największą liczbę uczniów w szkołach zanotowano w powiecie wieluńskim oraz dwóch miastach: Skierniewicach i Piotrkowie Trybunalskim, gdzie liczba uczniów w liceach uzu- 
pełniających przekraczała 85 osób. Najwyższą wartość wykazywano w przypadku Piotrkowa Trybunalskiego, gdzie wskaźnik osiagnął wartość 92 uczniów na szkołę. W przypadku Skierniewic wysoka wartość wskaźnika pokrywa się z wnioskiem, dotyczącym możliwości korzystania ze szkół w nim zlokalizowanych, przez osoby z powiatu okalającego miasto.

Rysunek 25. Liczba uzupełniających liceów ogólnokształcących dla absolwentów zasadniczych szkół zawodowych na 1000 osób w wieku 19-20 lat

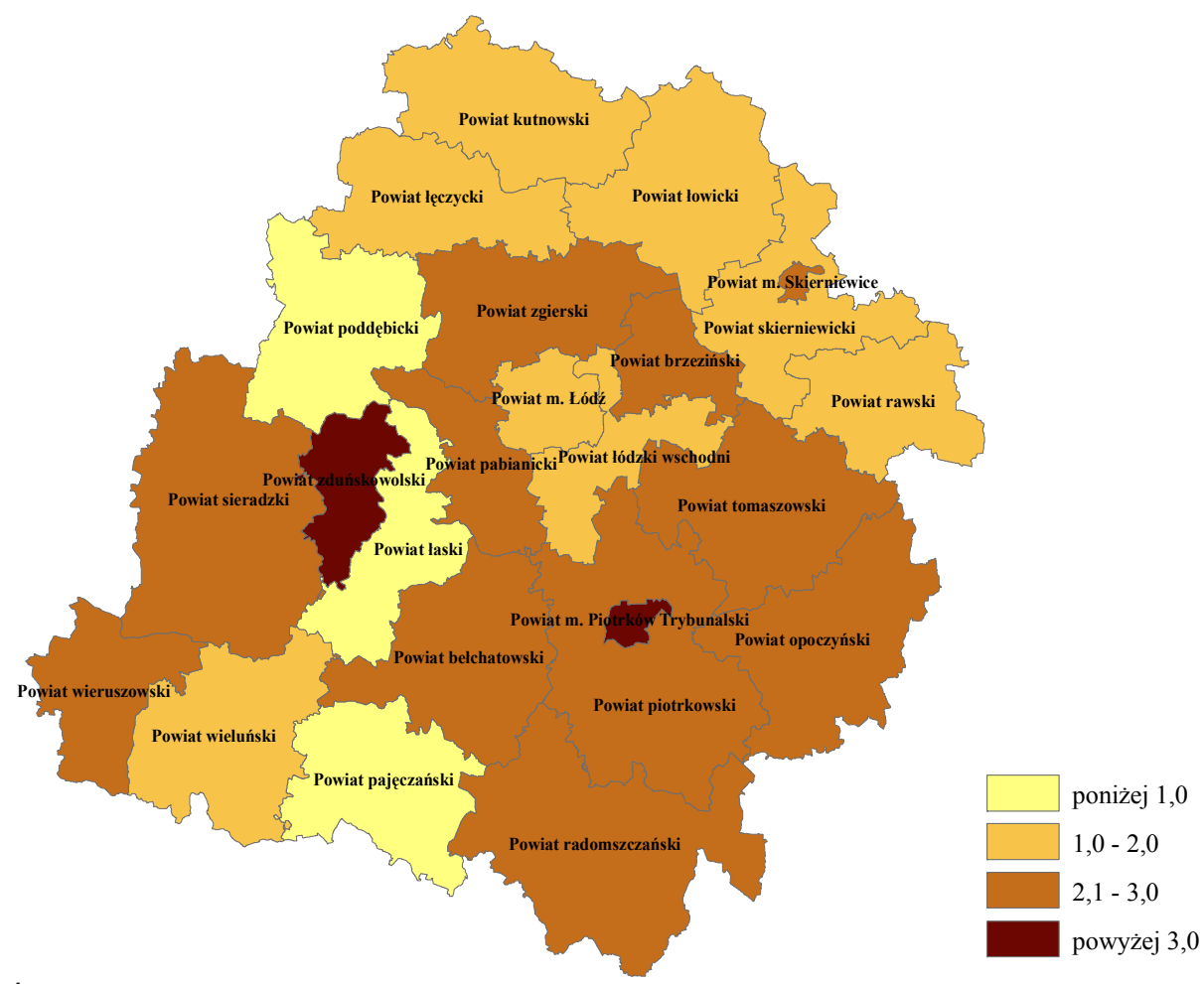

Źródło: Opracowanie własne na podstawie danych GUS i Systemu Informacji Oświatowej (SIO).

W województwie łódzkim średnia wielkość liceum uzupełniającego to 44 uczniów. $Z$ analizy wynika jednak, że szkoły niepubliczne są jednostkami większymi, gdyż kształci się w nich średnio 47 uczniów (w szkołach publicznych jest ich 34). W przypadku średnich wartości notowanych dla Polski jest podobnie. Średnia wielkość liceum uzupełniającego, mierzona liczbą wychowanków wynosi 57 uczniów. W przypadku szkół publicznych jest to 48 uczniów, natomiast w szkołach niepublicznych naukę pobierają 63 osoby. 
Rysunek 26. Liczba uczniów przypadająca na jedno uzupełniające liceum ogólnokształcące dla absolwentów zasadniczych szkół zawodowych

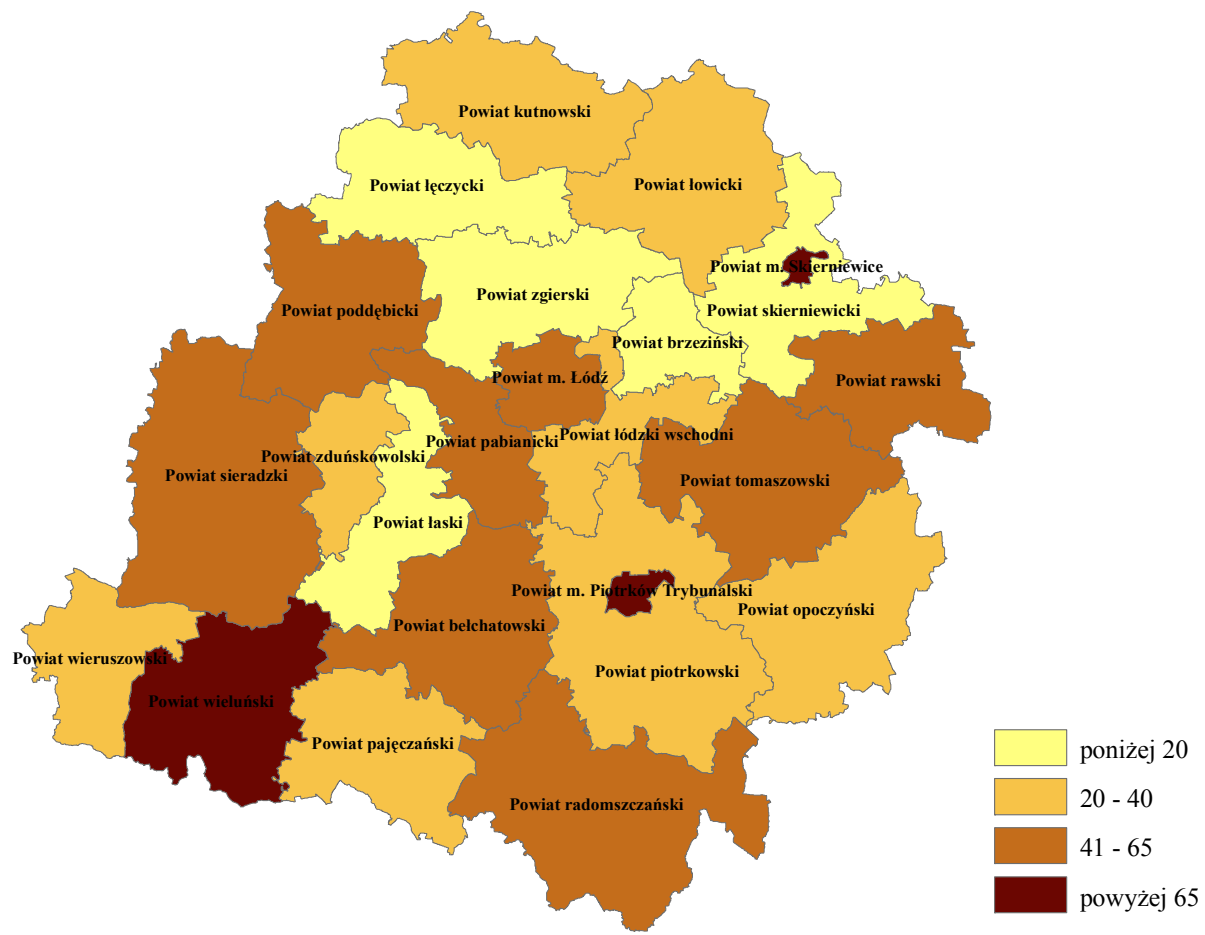

Źródło: Opracowanie własne na podstawie Systemu Informacji Oświatowej (SIO).

Jeżeli chodzi o uzupełniające technika dla absolwentów zasadniczych szkół zawodowych, wykazują one mniejszą dostępność niż licea uzupełniające. W trzech powiatach: brzezińskim, łaskim i skierniewickim nie zlokalizowano żadnej placówki tego rodzaju, natomiast w łódzkim wschodnim, pajęczańskim, piotrkowskim i sieradzkim ich liczba nie przekracza 0,8 szkoły na 1000 osób w wieku 19-20 lat. Najniższą wartością charakteryzuje się powiat łódzki wschodni, gdzie zlokalizowane jest zaledwie 0,5 jednostki na 1000 osób w wieku 19-20 lat.

Największą dostępnością techników uzupełniających charakteryzują się powiaty: łowicki i opoczyński oraz Piotrków Trybunalski. Wartości wskaźnika w tych powiatach przekraczają 1,8 techników na 1000 osób w wieku 19-20 lat. Najlepiej sytuacja przedstawia się w powiecie opoczyńskim, gdzie omawiany wskaźnik wynosi 2,5. 
Rysunek 27. Liczba uzupełniających techników dla absolwentów zasadniczych szkół zawodowych na 1000 osób w wieku 19-20 lat

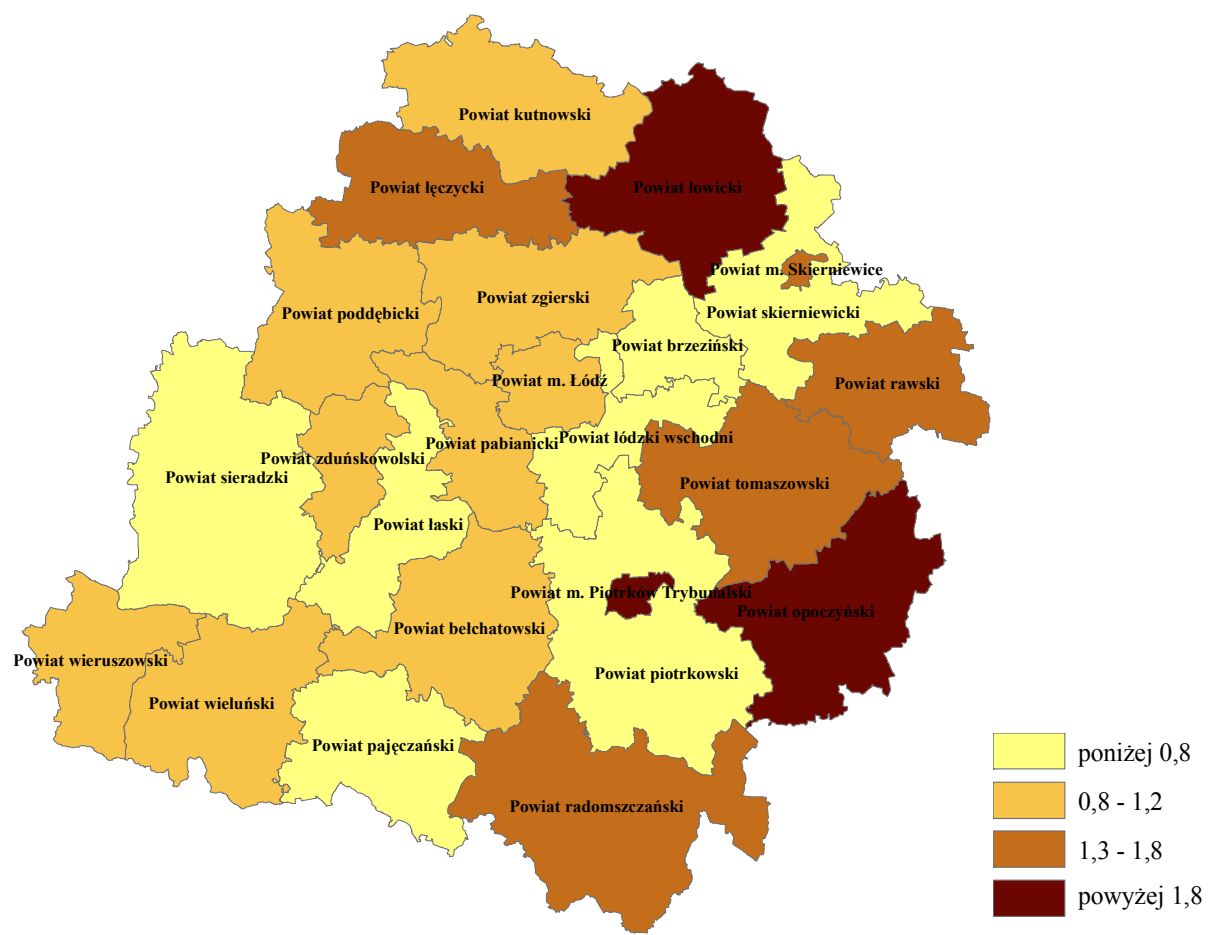

Źródło: Opracowanie własne na podstawie danych GUS i Systemu Informacji Oświatowej (SIO).

Niską liczbą uczniów w technikach uzupełniających charakteryzują się powiaty: łęczycki, łódzki wschodni, zduńskowolski i zgierski. W powiatach tych istniejące technika mają średnio poniżej 10 uczniów. W łódzkim wschodnim, pomimo istnienia szkoły nie posiada ona żadnego ucznia. Najmniejsze placówki tego rodzaju zlokalizowane są w powiecie zduńskowolskim i zgierskim, gdzie liczba uczniów wynosi 8 .

Mimo dużej dostępności techników uzupełniających, duża liczba uczniów, przypadająca na jedną placówkę charakteryzuje powiat opoczyński oraz Piotrków Trybunalski. W grupie powiatów o najwyższej średniej liczbie uczniów na szkołę znalazł się również powiat bełchatowski. Wszystkie jednostki terytorialne charakteryzują się liczbą uczniów wyższą niż 60 na szkołę. Na czoło w statystykach wysuwa się Piotrków Trybunalski, ze wskaźnikiem na poziomie 110 uczniów. Pozwala to wnioskować, że szczególnie w tym mieście technika uzupełniające cieszą się zainteresowaniem uczniów. 
Rysunek 28. Liczba uczniów przypadająca na jedno technikum uzupełniające dla absolwentów zasadniczych szkół zawodowych

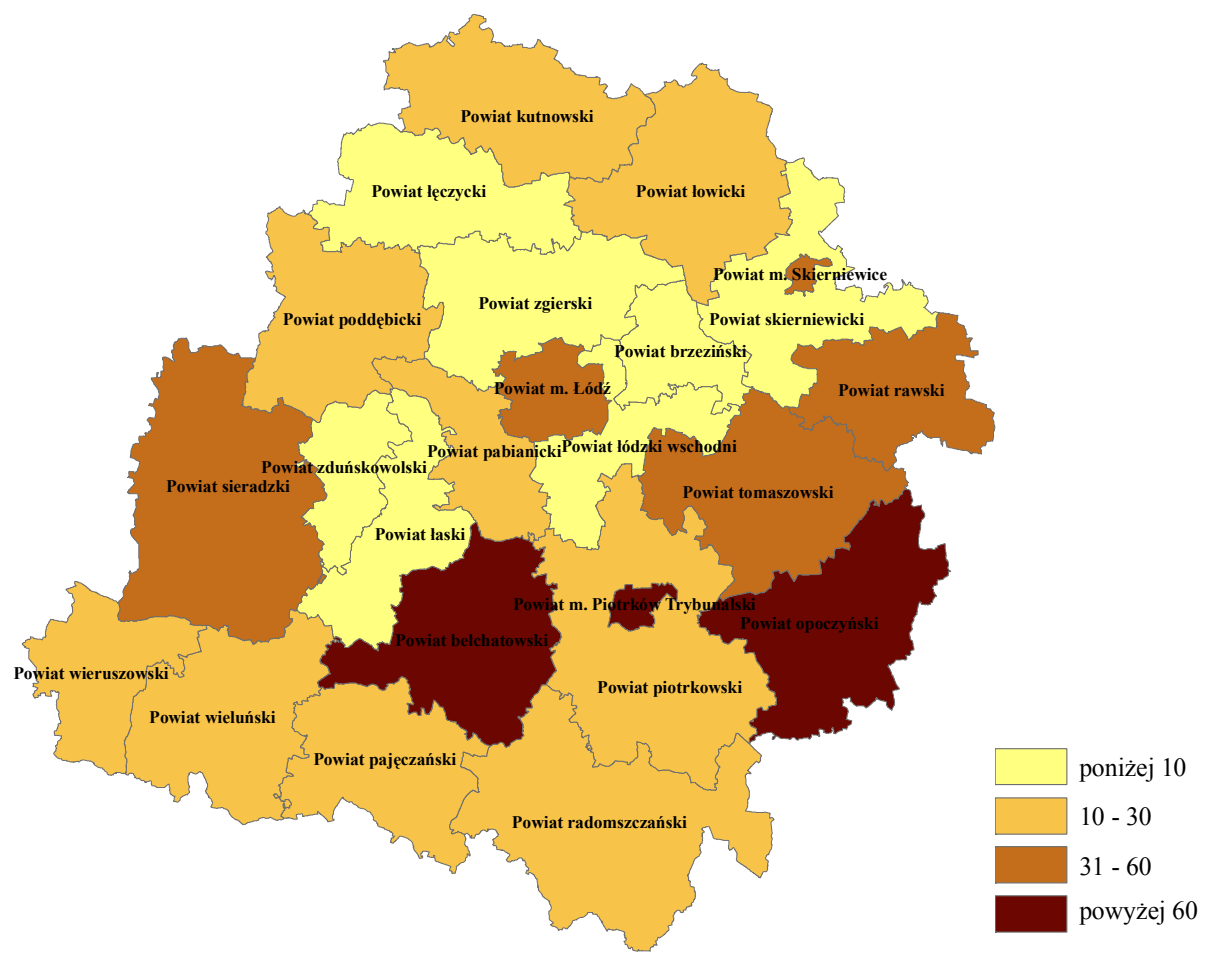

Źródło: Opracowanie własne na podstawie Systemu Informacji Oświatowej (SIO).

Osoby, które posiadają wykształcenie średnie ${ }^{23}$, mogą kontynuować naukę w szkołach policealnych, gdzie mają możliwość zdobycia dyplomów potwierdzających wyuczenie określonego zawodu. Znaczna większość szkół policealnych to szkoły niepubliczne, które stanowią 72,8\% wszystkich szkół policealnych w województwie łódzkim.

W województwie łódzkim trzy powiaty nie mają na swoim obszarze szkół policealnych. Są to powiaty: brzeziński, łaski i łódzki wschodni. Niską dostępnością tego rodzaju szkół charakteryzuje się powiat kutnowski oraz jednostki terytorialne w południowo-zachodniej części województwa, tj. powiaty: pajęczański, wieluński i wieruszowski. W przypadku pajęczańskiego i wieruszowskiego omawiany wskaźnik ma poziom zaledwie 0,5 szkoły na 1000 osób

${ }^{23}$ Zgodnie z artykułem 11a ustawy z dnia 7 września 1991 r. o systemie oświaty, Dz. U. 1991 $\mathrm{Nr} 95$, poz. 425 , z późn. zmianami, są to osoby, które ukończyły szkołę ponadgimnazjalną z wyjątkiem zasadniczej szkoły zawodowej oraz trzyletniej szkoły specjalnej przysposabiającej do pracy. 
w wieku 19-20 lat. Największą dostępnością szkół policealnych charakteryzują się: Piotrków Trybunalski i Skierniewice. Liczba tych placówek przekracza tam liczbę 4. Na czoło jednak wysuwa się Piotrków Trybunalski, gdzie wartość omawianej wielkości wynosi 7,4.

Rysunek 29. Liczba szkół policealnych na 1000 osób w wieku 19-20 lat

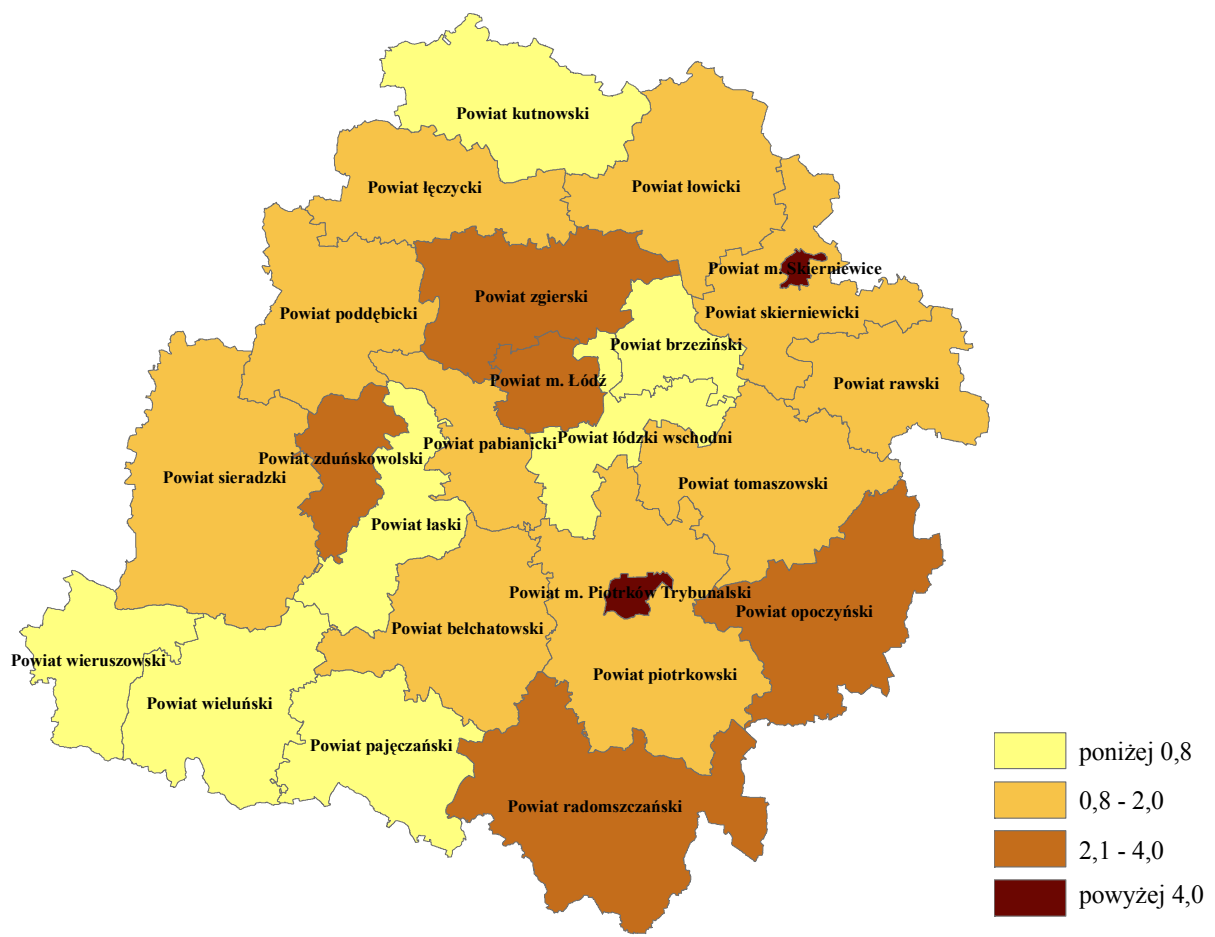

Źródło: Opracowanie własne na podstawie danych GUS i Systemu Informacji Oświatowej (SIO).

Najmniejszą liczebnością w szkołach policealnych odznaczają się powiaty: łęczycki, pajęczański, poddębicki, skierniewicki i zgierski. Liczba uczniów tych szkół jest mniejsza niż 30 osób. Najniższą wartość wskaźnika stwierdzono w powiecie zgierskim, gdzie wynosi on 14 osób na szkołę policealną.

Województwo łódzkie charakteryzuje się średnią wielkością szkoły policealnej na poziomie 88 uczniów. Należy podkreślić, że do szkół publicznych uczęszcza średnio 80 uczniów, a do niepublicznych 100. Pozwala to stwierdzić, że szkoły w województwie łódzkim są większe niż ma to miejsce w Polsce. Wskaźniki te dla poziomu kraju wynoszą odpowiednio: 75 osób (średnia liczba uczniów w szkołach policealnych), 55 osób (szkoły publiczne), 83 osoby (szkoły niepubliczne). 
Rysunek 30. Liczba uczniów przypadająca na szkołę policealną

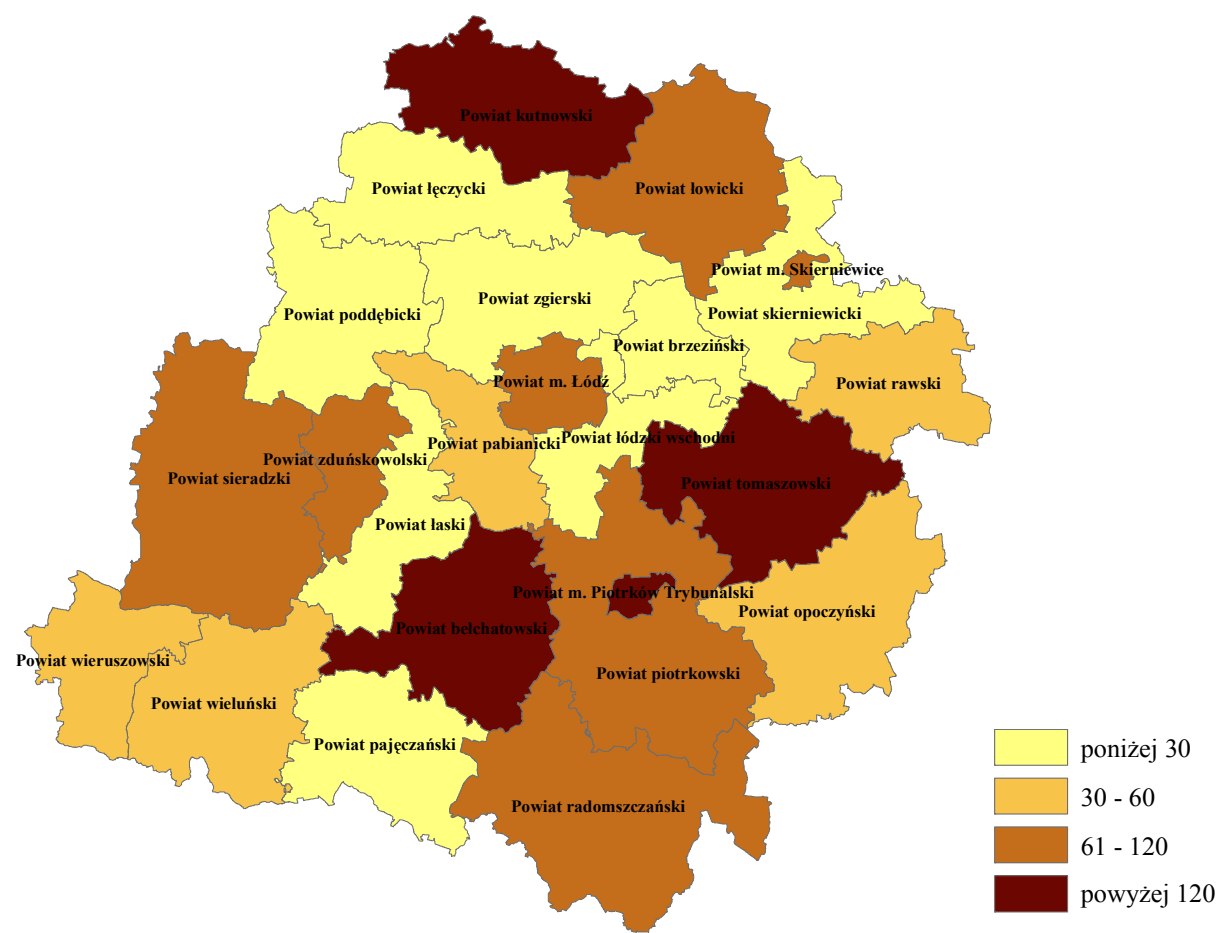

Źródło: Opracowanie własne na podstawie Systemu Informacji Oświatowej (SIO).

\section{Szkoły artystyczne w województwie łódzkim}

Kształcenie artystyczne odbywa się na różnych poziomach kształcenia i dotyczy szkół muzycznych, plastycznych, szkół sztuki tańca, szkół baletowych, szkół sztuki cyrkowej oraz szkół kształcących w zakresie animacji kultury. Szkoły te mają duży wpływ na rozwój kapitału ludzkiego oraz kreatywność jednostek. Wykazują szeroki wachlarz przedmiotów kształcenia, dzięki czemu pozwalają na indywidualny rozwój uczniów, poprzez ich świadomy wybór ścieżki kształcenia.

W województwie łódzkim znajduje się $6,4 \%{ }^{24}$ wszystkich szkół artystycznych w Polsce. Są to szkoły o różnych profilach kształcenia zarówno publiczne,

${ }^{24} \mathrm{Z}$ uwagi na małą liczbę szkół artystycznych w podziale rodzajowym, w artykule zostaną one omówione w sposób całościowy. Opis dotyczyć będzie: sześcioletnich ogólnokształcących szkół muzycznych I stopnia, sześcioletnich szkół muzycznych I stopnia, czteroletnich szkół muzycznych I stopnia, sześcioletnich ogólnokształcących szkół muzycznych II stopnia, sześcioletnich szkół muzycznych II stopnia, sześcioletnich ogólnokształcących szkół sztuk pięknych, czteroletnich liceów plastycznych, dziewięcioletnich ogólnokształcących szkół baletowych, sześcioletnich 
jak i niepubliczne. W łódzkich szkołach kształci się w nich blisko 7\% uczniów tych jednostek. W województwie łódzkim $24 \%$ szkół artystycznych to jednostki niepubliczne, w tym $18,5 \%$ to placówki z uprawnieniami szkół publicznych. W skali kraju wskaźnik szkół niepublicznych wynosi $33 \%$, w tym $14,7 \%$ to szkoły z uprawnieniami.

Szkół artystycznych w województwie łódzkim nie zlokalizowano w siedmiu powiatach: łaskim, łódzkim wschodnim, pajęczańskim, piotrkowskim, rawskim, skierniewickim i wieruszowskim. W stolicy województwa siedzibę ma dziewiętnaście szkół artystycznych. W pozostałych powiatach województwa liczba ta waha się od jednej do pięciu szkół artystycznych.

Rysunek 31. Liczba szkół artystycznych w województwie łódzkim

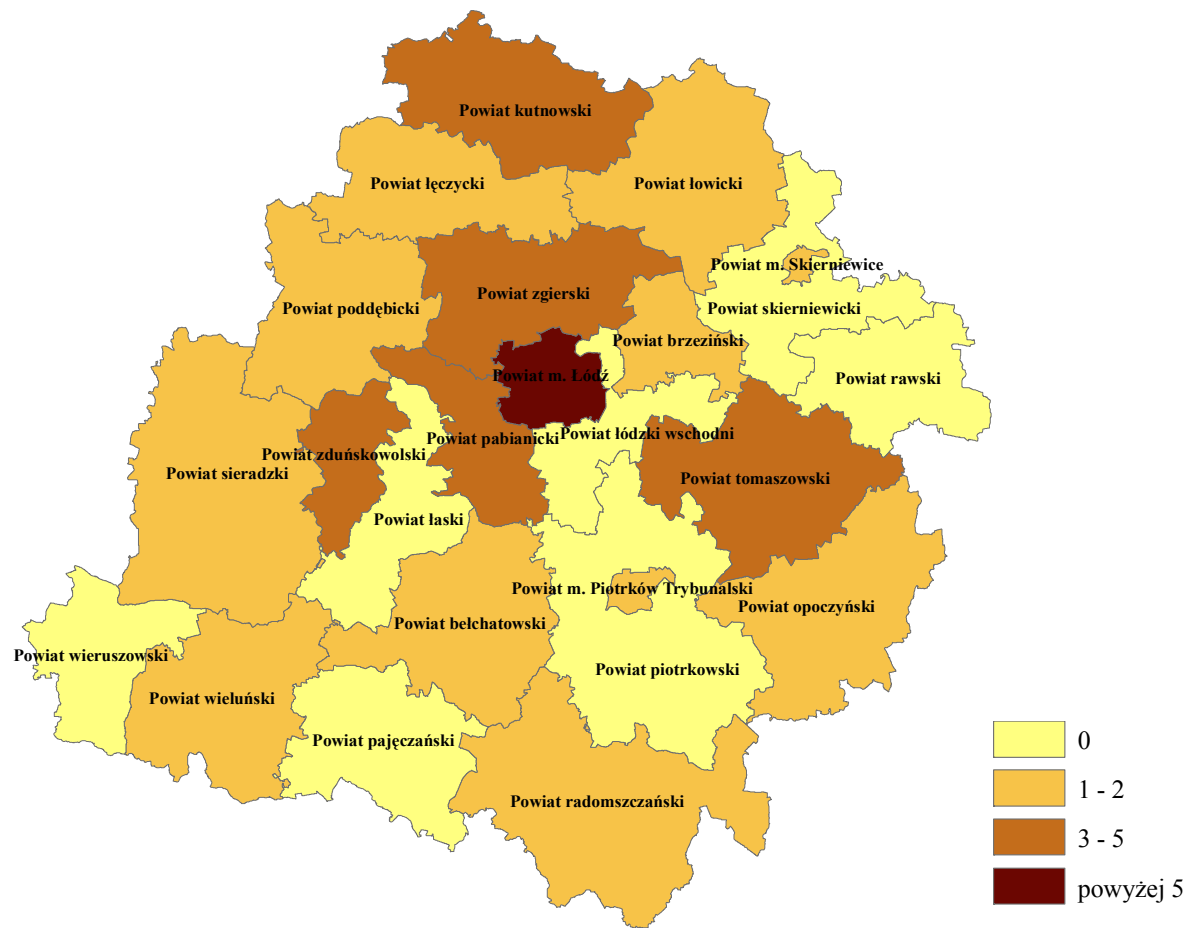

Źródło: Opracowanie własne na podstawie Systemu Informacji Oświatowej (SIO).

szkół sztuki tańca, czteroletnich szkół sztuki cyrkowej, policealnych szkół artystycznych, pomaturalnych szkół animatorów kultury, czteroletnich szkół muzycznych II stopnia, dziewięcioletnich szkół sztuki tańca oraz Poznańskiej Szkoły Chóralnej. 
Najmniejsze pod względem liczby uczniów szkoły artystyczne znajdują się w powiatach na północy województwa: kutnowskim, łęczyckim, łowickim i poddębickim. Podobna sytuacja miejsce ma w powiatach: opoczyńskim, pabianickim, tomaszowskim i zduńskowolskim. Liczba uczniów na szkołę nie przekracza tam 100 osób. Najniższą wartością wskaźnika charakteryzuje się powiat łęczycki, gdzie do szkół artystycznych uczęszcza średnio 49 uczniów. Największe pod względem liczebności wychowanków są szkoły w powiecie sieradzkim, gdzie wartość wskaźnika osiąga poziom 200 uczniów.

\section{Rysunek 32. Liczba uczniów przypadająca na szkołę artystyczną}

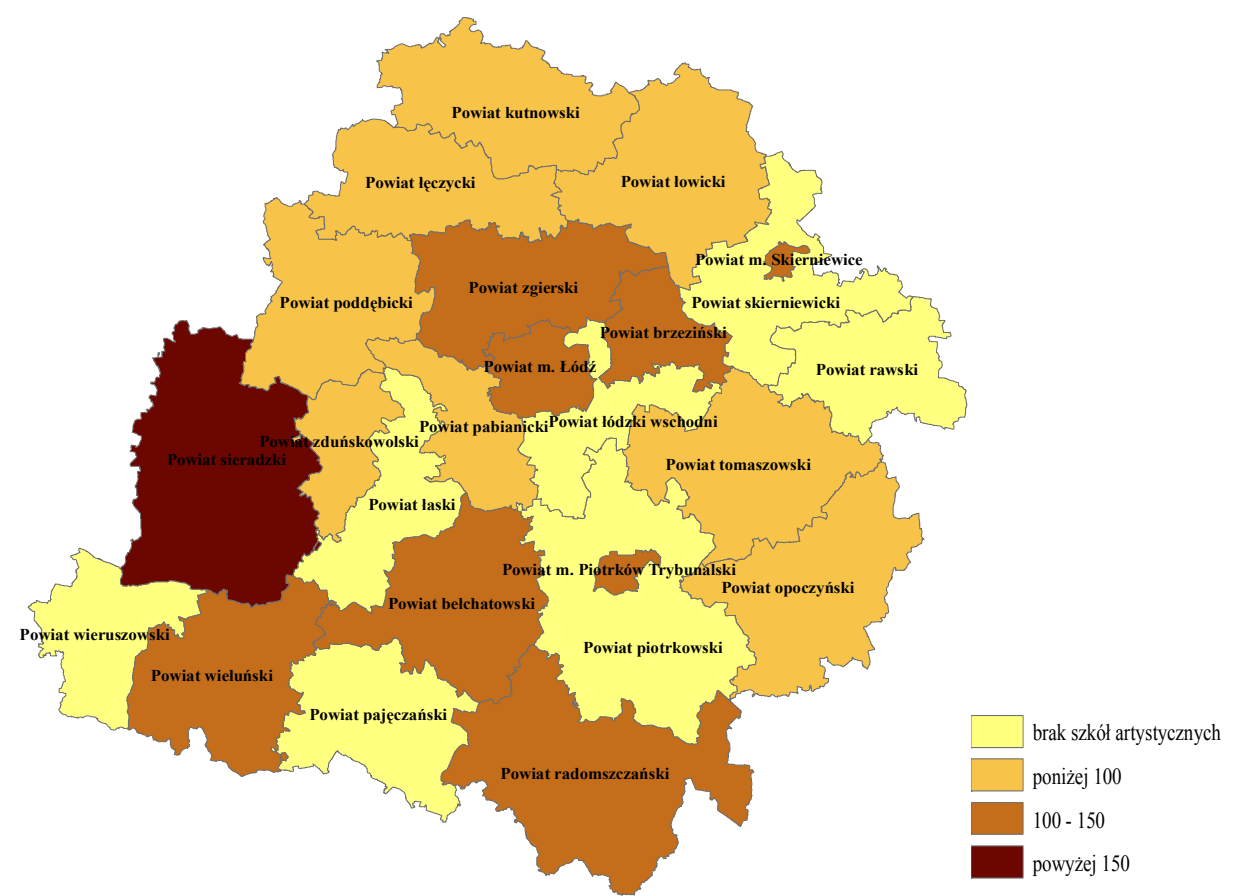

Źródło: Opracowanie własne na podstawie Systemu Informacji Oświatowej (SIO).

Średni wskaźnik liczby uczniów w szkole artystycznej dla województwa łódzkiego wynosi 95 uczniów na jednostkę. Jest to wskaźnik wyższy od notowanego w kraju, gdzie wartość jego wynosi 84 osoby. Wpływa to również na wartości wskaźnika, opisującego liczbę uczniów na jednego nauczyciela. W przypadku regionu łódzkiego jest to 16 uczniów na nauczyciela, natomiast wartość średnia dla Polski wynosi 15. 


\section{Kształcenie nauczycieli w województwie łódzkim}

Ważnym elementem w rozwoju kapitału ludzkiego w regionie jest możliwość doskonalenia i rozwoju kwalifikacji zawodowych przez nauczycieli. Tego rodzaju proces można nazwać kształceniem ustawicznym nauczycieli. Podnoszenie kwalifikacji samo w sobie wpływa na podnoszenie konkurencyjności na rynku i akumulację kapitału ludzkiego oraz w konsekwencji prowadzi do wyższego poziomu w procesie kształcenia dzieci i młodzieży.

Przyjęło się, że placówki stanowiące podstawę rozwoju kadry kształcącej organizowane są w postaci: kolegiów nauczycielskich, kolegiów nauczycielskich języka obcego, czy placówek doskonalenia nauczycieli. Ważnym elementem procesu dokształcania nauczycieli, jak również codziennego wsparcia dla kadry nauczycielskiej są biblioteki pedagogiczne. Rozwój i zasobność bibliotek pedagogicznych staje się elementem inwestycji w kapitał ludzki oraz stanowi źródło jego rozwoju, podobnie jak metody bezpośredniego inwestowania w procesie kształcenia i dokształcania nauczycieli.

Rysunek 33. Kolegia i placówki dokształcania nauczycieli według rodzaju

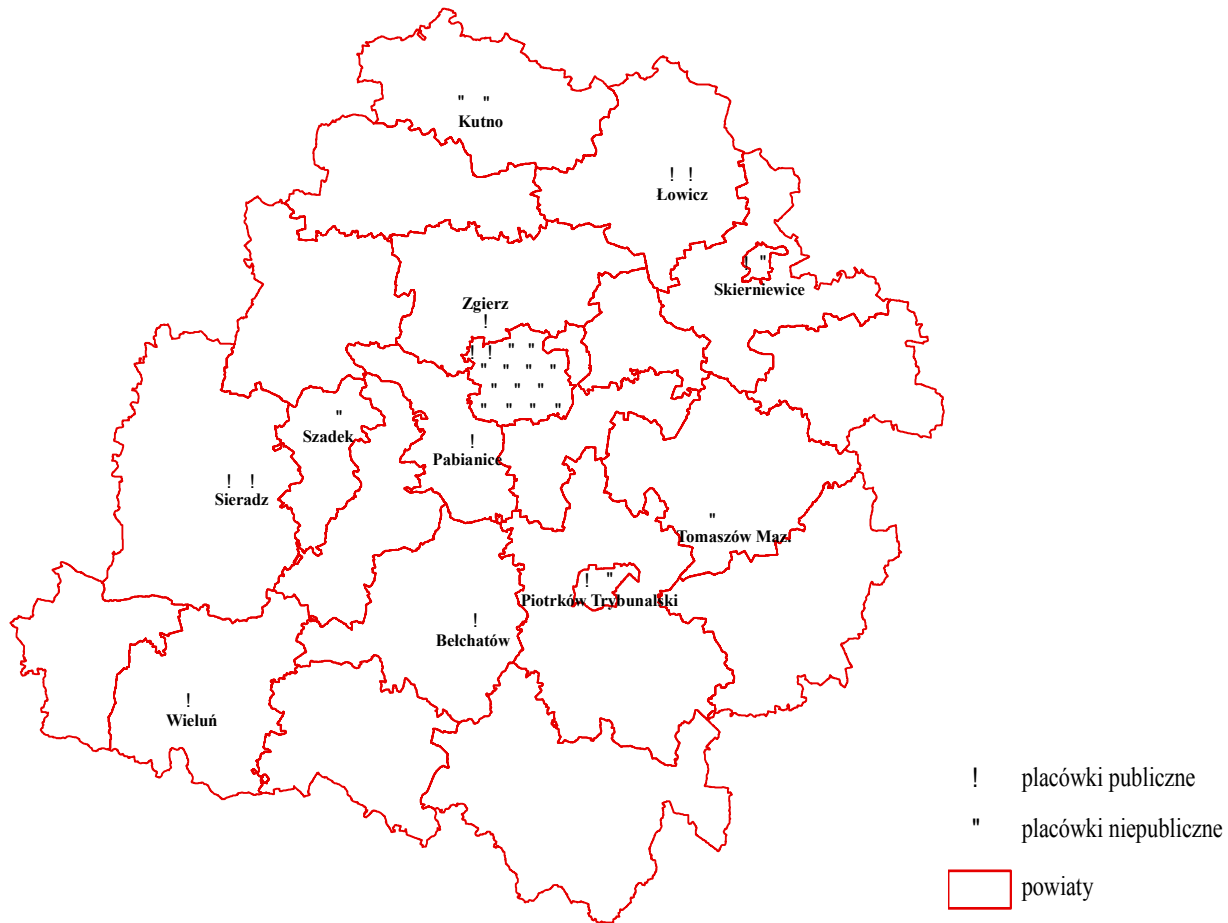

Źródło: Opracowanie własne na podstawie Systemu Informacji Oświatowej (SIO). 
Kolegia i placówki doskonalenia nauczycieli zlokalizowane w województwie łódzkim stanowią 6,2\% wszystkich jednostek działających w Polsce. W regionie łódzkim blisko $65 \%$ tych placówek ma charakter niepubliczny, co w porównaniu do wartości średniej w Polsce jest wskaźnikiem o 1 p. p. niższym. W przypadku bibliotek pedagogicznych, w regionie łódzkim mieści się 7\% jednostek. Ich rozmieszczenie w regionie pozwala zauważyć, że jedynie w powiatach: łódzkim wschodnim, piotrkowskim i skierniewickim nie zlokalizowano takich placówek. W przypadku tych jednostek terytorialnych może zostać to usprawiedliwione poprzez bezpośrednie sąsiedztwo miast na prawach powiatów, w których znajdują się biblioteki pedagogiczne. W powiecie poddębickim zlokalizowano 2 tego rodzaju biblioteki. Pozostałe powiaty posiadaja po 1 bibliotece pedagogicznej.

Analiza rozmieszczenia kolegiów nauczycielskich i centrów dokształcania nauczycieli pokazuje, że najwięcej tego rodzaju ośrodków zlokalizowanych jest w Łodzi. Spośród 15 tego rodzaju jednostek w stolicy regionu zaledwie 2 mają charakter publiczny. W pozostałych ośrodkach, gdzie zlokalizowano kolegia i centra dokształcania ich liczba nie przekracza 2 jednostek. W przypadku Łowicza i Sieradza zidentyfikowano po 2 ośrodki o charakterze publicznym. W Piotrkowie Trybunalskim i Skierniewicach zlokalizowano również po 2 ośrodki, po 1 publicznej i niepublicznej, natomiast w Kutnie znajdują się 2 ośrodki doskonalenia nauczycieli o charakterze niepublicznym. W pozostałych miastach zlokalizowano po 1 tego rodzaju ośrodku, tj.: Bełchatów, Pabianice, Wieluń, Zgierz (jednostki publiczne), Szadek, Tomaszów Mazowiecki (jednostki niepubliczne).

Istnienie tego rodzaju instytucji wspierających system oświaty pozwala na rozwój i podnoszenie kwalifikacji nauczycieli. Jest to również element służący ocenie rozwoju regionu w programach operacyjnych, szczególnie w PO KL. Teoretyczne i praktyczne przygotowanie, które uzyskują nauczyciele wpływa na wyższy poziom wykonywania zadań wychowawczych i nauczycielskich, co staje się elementem wpływającym na rozwój kapitału ludzkiego w sposób pośredni i bezpośredni.

\section{Podsumowanie}

System oświaty w województwie łódzkim prezentuje wysoki stopień integracji pomiędzy poziomami kształcenia, który wynika z zapisów ustawy o systemie oświaty ${ }^{25}$. Analizy przeprowadzone na poziomie agregacji powiatów wskazują, że poszczególne jednostki terytorialne województwa dopełniają się

${ }^{25}$ Ustawa z dnia 7 września 1991 r. o systemie oświaty, Dz. U. 1991 Nr 95, poz. 425, z późn. zmianami. 
w zakresie dostępności szkół. Widać to w szczególności na poziomie kształcenia ponadgimnazjalnego. Ważnym elementem rozwoju kapitału ludzkiego w województwie i jego poszczególnych powiatach stają się szkoły artystyczne, które pozwalają na rozwój indywidualnych cech uczniów. Swego rodzaju indywidualizm kształcenia w tych ośrodkach, wpływa pozytywnie na rozwój kapitału ludzkiego, który z teorii cechuje się indywidualnością i niepowtarzalnością.

Ważnym wnioskiem wynikającym z analizy jest fakt, że kształcenie podstawowe, gimnazjalne i ponadgimnazajalne wykazuje się dobrą dostępnością w poszczególnych powiatach. Elementem dopełniającym popularność szkół jest i będzie w przyszłości podnoszenie jakości kształcenia, wykorzystanie w edukacji nowych metod nauczania oraz ciagła poprawa warunków kształcenia, poprzez zapewnienie klas o odpowiedniej liczbie uczniów oraz wprowadzanie nowoczesnych pomocy naukowych. Wpływ na osiagnięcie rozwoju w tym zakresie uzależniony będzie od dostępności finansów, które w przypadku szkół rozdysponowywane są przez władze lokalne.

Istotnym elementem systemu edukacji są nauczyciele, którzy aby utrzymać wysoki poziom kwalifikacji powinni stale je podnosić, utrzymując tym samym wysoki poziom swojej konkurencyjności na rynku. Permanentne podnoszenie kwalifikacji kadry nauczycielskiej, jest warunkiem niezbędnym do kształtowania wysokiej jakości kapitału ludzkiego w regionie i środowisku lokalnym. Odbywać się to może, poprzez wykorzystanie zaplecza instytucji podnoszenia kwalifikacji zawodowych nauczycieli zlokalizowanych w regionie.

Istotne $\mathrm{z}$ punktu widzenia rozwoju kapitału ludzkiego w województwie łódzkim jest również dostosowywanie programów kształcenia do wymogów stawianych przez rynek. Elastyczne szkolnictwo poprawi konkurencyjność regionu oraz kształcących się w nim uczniów. Elementem rozwoju kapitału ludzkiego w województwie łódzkim, może stać się również dalsze promowanie modelu kształcenia kierunkowego, a nie ogólnokształcącego. Podejście takie pozwoli również na rozwój współpracy między sektorem nauczania a przedsiębiorcami, w celu pokrycia podaży miejsc pracy w konkretnych zawodach na lokalnych i regionalnych rynkach pracy. Rozwój projektu „Zawodowo dla Łodzi”, realizowanego $\mathrm{w}$ województwie łódzkim, powinien być rozpowszechniony w większości szkół technicznych i zawodowych, w celu promocji tego modelu kształcenia. 
116 Dostępność systemu oświaty w województwie łódzkim...

\section{Bibliografia}

Babalola J. B., Budget Preparation and Expenditure Control in Education [w:] Basic Text in Educational Planning, Babalola J. B. (red.), Ibadan Awemark Industrial Printers 2003 [za:] D. A. Olaniyan, T. Okemakinde, Human Capital Theory: Implications for Educational Development [w:] European Journal of Scientific Research, Dec 2008, Vol. 24 Issue 2,EBSCO.

Nowakowska A., Przygodzki Z., Sokołowicz M. E., Region w gospodarce opartej na wiedzy. Kapitat ludzki, innowacje, korporacje transnarodowe, Wydawnictwo Difin, Warszawa 2011.

Olaniyan D. A., Okemakinde T., Human Capital Theory: Implications for Educational Development [w:] European Journal of Scientific Research, Dec 2008, Vol. 24 Issue 2; EBSCO.

Rozporządzenie Ministra Edukacji Narodowej z dnia 21 maja 2001 r. w sprawie ramowych statutów publicznego przedszkola oraz publicznych szkół, z późn. zmianami.

Ustawa z dnia 7 września 1991 r. o systemie oświaty, Dz. U. 1991 Nr 95, poz. 425, z późn. zmianami.

Vandenberghe V., Economics of Education. The Need to go Beyond Human Capital Theory and Production-Function Analysis [w:] Educational Studies, Jul 99, Vol. 25 Issue 2, EBSCO. 